\title{
Insulin Signalling in Human Adipocytes and its Interplay with beta-Adrenergic Control of Lipolysis
}

\author{
Cecilia Jönsson
}

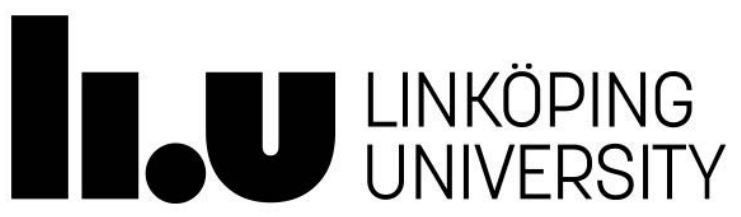

Department of Clinical and Experimental Medicine

Faculty of Medicine and Health Sciences, Linköping University, Sweden Linköping 2018 
Cover: Fluorescence microscopic image demonstrating the association of caveolin-1 and IQGAP1 (paper II). In a proximity ligation assay each red dot represents a single IQGAP1 caveolin-1 complex stained with Hoechst, nucleus is stained with DAPI.

(C) Cecilia Jönsson 2018

Published articles in this thesis have been reprinted with the permission of respective copyright holders.

ISBN: 978-91-7685-285-9

ISSN: 0345-0082

Printed by LiU-Tryck, Linköping 2018

During the course of the research underlying this thesis, Cecilia Jönsson was enrolled in Forum Scientium, a multidisciplinary doctoral program at Linköping University, Sweden 



\section{Supervisor}

\section{Professor Peter Strålfors}

Department of Clinical and Experimental Medicine

Linköping University

\section{Co-supervisor}

\section{Docent Maria Turkina}

Department of Clinical and Experimental Medicine Linköping University

\section{Faculty Opponent}

\section{Professor Jan Eriksson}

Department of Medical Sciences

Uppsala University 


\section{Abstract}

The prevalence of obesity has over the last 40 years nearly tripled and obesity is one of the major risk factors of developing type 2 diabetes. Type 2 diabetes was formerly called adultonset diabetes but today, probably due to the rise in childhood obesity, it is also seen in children and adolescents. Type 2 diabetes is diagnosed when the body no longer can control the glucose levels in the blood. This is due to an insulin resistant state in the insulin responding tissues, liver, adipose and muscle and insufficient production of insulin in the pancreas. However, in spite of extensive research the mechanisms behind insulin resistance is still not known.

The adipose tissue is believed to play a major role in the development of whole body insulin resistance. Adipocytes are the most important sites for storage of the high energy containing triacylglycerols. Insulin stimulation causes the adipocyte to increase the uptake of glucose and to reduce lipolysis: the hydrolysis of triacylglycerol and release of glycerol and fatty acids. The insulin signalling network is complex with numerous proteins involved. These signalling proteins not only transmit the insulin signal but also create negative and positive feedbackloops and induce cross talk between different parts of the network and with the signalling of other hormones. One important positive feedback in insulin signalling is the mTORC1 mediated feedback to phosphorylation of IRS1 at serine 307. In paper I we found that in human adipocytes this feedback is not likely catalysed by the assumed kinase S6K1. However we find an immunoprecipitate of mTOR to contain a ser307 phosphorylating kinase.

Scaffolding proteins serve as docking sites for several proteins to promote protein-protein interactions that facilitate signal transduction. In paper II we demonstrate the existence of the scaffolding protein IQGAP1 in human adipocytes and that the expression of IQGAP1 is downregulated in type 2 diabetes. We reveal that IQGAP1 co-localises with caveolae, invaginations of the plasma membrane where the insulin receptor is situated, and that this interaction is increased upon insulin stimulation.

In paper III we focus on the control of lipolysis, and sought to understand the interplay between insulin and beta-adrenergic stimulation. We demonstrated that the re-esterification of fatty acids is downregulated in type 2 diabetes causing an increased release of fatty acids from the cells. We showed that beta-adrenergic stimulation with isoproterenol induced a negative feedback via PKA/Epac1 -> PI3K -> PKB -> PDE3B that reduced the cAMP levels and thereby also reduced lipolysis. We also showed that insulin, in addition to its well-known anti-lipolytic effect, at high concentrations had a positive effect on lipolysis. In conclusion we reveal an intricate control of the stimulation as well as the inhibition of lipolysis induced by both isoproterenol and insulin. 



\section{Populärvetenskaplig sammanfattning}

Typ 2 diabetes, även kallad åldersdiabetes, är en av de vanligaste icke-smittsamma sjukdomarna i världen. Flera hundra miljoner människor har idag diagnosen typ 2 diabetes och det finns även många människor som har diabetes utan att veta om det. Sjukdomen beror till stor del på övervikt och fetma och den ökade utbredningen av fetma över alla åldrar har lett till att även unga drabbas av sjukdomen idag. Ett förstadium till typ 2 diabetes är insulinresistens, som betyder att insulin som frisätts efter en måltid inte längre har samma förmåga att påverka lever, muskler och fettväv att ta upp och lagra socker, vilket leder till höga koncentrationer av socker i blodet. Höga blodsockernivåer kan i sin tur leda till skador i kroppen.

Eftersom fetma är den största riskfaktorn för att utveckla typ 2 diabetes och att insulinresistensen troligen uppstår i fettväven har arbetet i den här avhandlingen fokuserat på fettceller. För att försöka förstå hur insulinresistens uppstår i fettcellerna har vi undersökt hur insulinsignaleringen sker i celler från friska kvinnor och hur den skiljer sig i celler från typ 2 diabetiker.

I små inbuktande strukturer, som kallas caveolae, i fettcellens yttermembran sitter insulinreceptorer. Dessa receptorer löper genom membranet och när insulin binder till receptorn utanpå cellen kan en signal föras vidare inuti cellen. Insulinsignaleringen består av ett komplext nätverk av proteiner som i kedjor påverkar varandra genom att släppa fram eller stänga av signalen, ofta genom att fästa fosfatgrupper (små molekyler som innehåller fosfor) på varandra som fungerar som på-och avknappar, vilket vi har studerat. Det behövs även proteiner som fungerar som byggnadsställningar och håller samman olika proteiner så att de kommer nära varandra. Vi har visat att ett sådant protein, IQGAP1, finns i fettceller och binder till caveolae och att inbindningen ökar vid insulinstimulering. Vi visar även att proteinnivåerna av IQGAP1 är mycket lägre i celler från diabetiker än från friska.

En av fettcellernas primära uppgift är att lagra fett i form av triacylglycerol i en stor fettdroppe i cellen. Vid fettnedbrytning i fettcellerna omvandlas triacyglycerol till glycerol och tre fettsyror som transporteras ut ur cellen. En del av fettsyrorna kan även återanvändas och på nytt bilda triacylglycerol, medan glycerol inte kan återanvändas av fettcellen. Insulinstimuleringen som sker efter en måltid leder till att fettcellerna hämmar sin nedbrytning och frisättning av fett, och istället lagrar upp mer fett som triacylglycerol. Mellan måltider eller vid fasta, då kroppen är i behov av energi, minskar insulinnivåerna i blodet och fettcellerna påverkas istället av noradrenalin som leder till ökad fettfrisättning. Vi har stimulerat fettceller med insulin och en noradrenalin-liknande molekyl, isoproterenol, och kunde visa att 
fettsyrafrisättningen är $50 \%$ högre vid typ 2 diabetes medan glycerolfrisättningen är opåverkad. Det vill säga återanvändningen av fettsyror är lägre hos diabetiker än hos friska, vilket kan vara orsaken till de förhöjda nivåerna av fettsyror i blodet hos diabetiker. Vi visar även att signalkedjorna som påverkas av insulin och noradrenalin är starkt sammanlänkade. Genom att fästa fosfatgrupper på olika proteiner involverade $\mathrm{i}$ insulinsignalering leder även noradrenalinstimulering till hämning av fettfrisättningen, troligen för att fettnedbrytningen ska ske balanserat under kontrollerade former. Insulin kan vid höga koncentrationer även öka fettfrisättningen genom att stänga av sin egen signal. 


\section{List of original papers}

This thesis is based on the following papers, referred to in the text by their roman numerals.

Meenu Rohini Rajan*, Siri Fagerholm*, Cecilia Jönsson*, Preben Kjølhede, Maria V. Turkina, Peter Strålfors

Phosphorylation of IRS1 at Serine 307 in Response to Insulin in Human Adipocytes Is Not Likely to be Catalyzed by p70 Ribosomal S6 Kinase PloS One 2013, 8(4):e59725

II

Åsa Jufvas, Meenu Rohini Rajan, Cecilia Jönsson, Peter Strålfors, Maria Turkina

Scaffolding protein IQGAP1 - an insulin-dependent link between caveolae and the cytoskeleton in primary human adipocytes?

Biochemical Journal, 2016, 473(19), 3177-3188

III

Cecilia Jönsson, Ana P. Castor Batista, Preben Kjølhede and Peter Strålfors Both insulin and $\beta$-adrenergic receptors mediate lipolytic and anti-lipolytic effects that are not affected by type 2 diabetes in human adipocytes Manuscript

*Authors contributed equally to the work 


\section{Abbreviations}

4EBP1 eukaryotic translation initiation factor 4E-binding protein 1

AGPAT acylglycerol-3-P acyltransferase

AMPK AMP-activated protein kinase

AR adrenergic receptor

AS160 Akt substrate of $160 \mathrm{kDa}$

ATGL adipose triglyceride lipase

BMI body mass index

C/EBP CCAAT/enhancer-binding protein

CGI-58 comparative gene identification 58

ChREBP $\beta$ carbohydrate-responsive element-binding protein

DAG diacylglycerol

DGAT diacylglycerol acyltransferase

EHD2 EH domain-containing protein 2

EPAC1 exchange protein directly activated by cAMP-1

ERK extracellular signal-regulated kinase

FA fatty acid

FASN fatty acid synthase

FKBP12 $12 \mathrm{kDa}$ FK506-binding protein

FOXO1 forkhead box protein $\mathrm{O} 1$

G3P glycerol-3-phosphate

GLUT4 glucose transporter 4

GPAT glycerol-3-P acyltransferase

GPCR G-protein coupled receptor

GSK3 glycogen synthase kinase

GyK glycerol kinase

HSP90 heat shock protein 90

IQGAP1 protein IQ motif-containing GTPase activating protein-1

IR insulin receptor

IRS insulin receptor substrate

JNK c-Jun N-terminal kinase

LC-MS/MS Liquid chromatography-tandem mass spectrometry

MAG monoacylglycerol

MGL monoglyceride lipase

mLST8 mammalian lethal with SEC13 protein 8

mSIN1 mammalian stress-activated protein kinase-interaction protein 1

mTOR mammalian/mechanistic target of rapamycin

mTORC1 mammalian/mechanistic target of rapamycin in complex with raptor

mTORC2 mammalian/mechanistic target of rapamycin in complex with rictor

PDE3B phosphodiesterase-3B 


$\begin{array}{ll}\text { PDK1 } & \text { phosphoinositide-dependent kinase-1 } \\ \text { PI3K } & \text { phosphatidylinositol 3-kinase } \\ \text { PIP2 } & \text { phosphatidylinositol }(4,5) \text { bisphosphate } \\ \text { PIP3 } & \text { phosphatidylinositol }(3,4,5) \text { trisphosphate } \\ \text { PKA } & \text { protein kinase A } \\ \text { PKB } & \text { protein kinase B } \\ \text { PKC } & \text { protein kinase C } \\ \text { PLA } & \text { proximity ligation assay } \\ \text { PLIN1 } & \text { perilipin 1 } \\ \text { PP2A } & \text { protein phosphatase 2A } \\ \text { PPAR } \gamma & \text { peroxisome proliferator-activated receptor gamma } \\ \text { PRAS40 } & \text { proline-rich AKT1 substrate-1 } \\ \text { PTRF } & \text { polymerase I and transcript release factor } \\ \text { RTK } & \text { receptor tyrosine kinase } \\ \text { S6 } & \text { ribosomal protein S6 } \\ \text { S6K1 } & \text { p70 ribosomal S6 kinase 1 } \\ \text { T2D } & \text { type 2 diabetes } \\ \text { TAG } & \text { triacylglycerol } \\ \text { TSC1/2 } & \text { tuberous sclerosis-1 and 2 protein } \\ \text { wt } & \text { wild type }\end{array}$





\section{Table of contents}

Introduction.............................................................................................................................

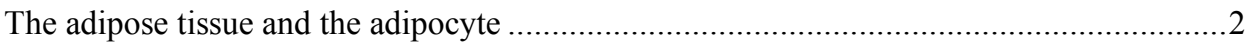

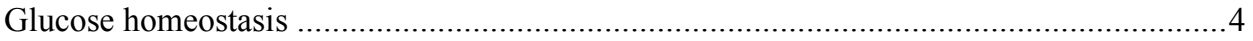

Insulin signalling in adipocytes ...............................................................................................5

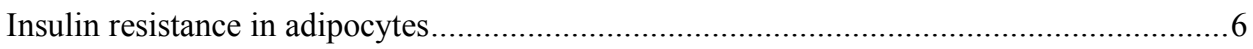

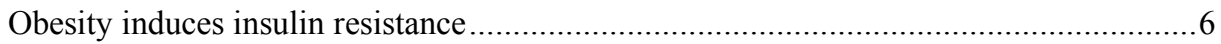

Selective insulin resistance ................................................................................

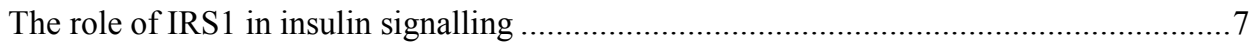

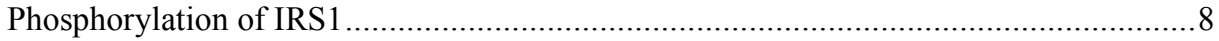

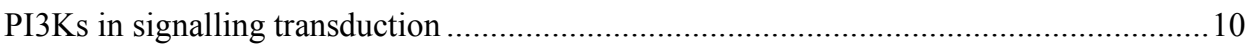

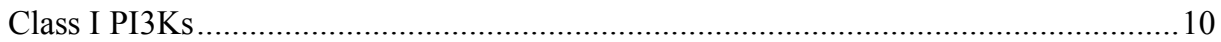

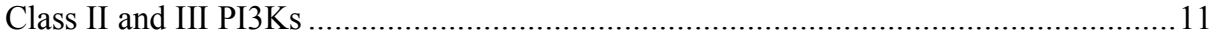

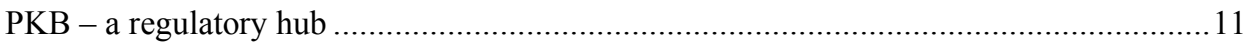

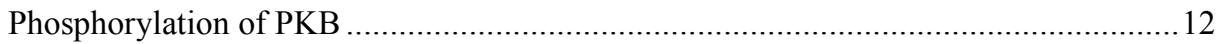

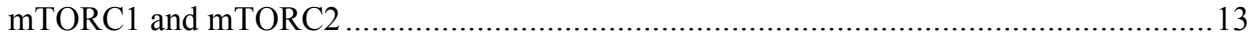

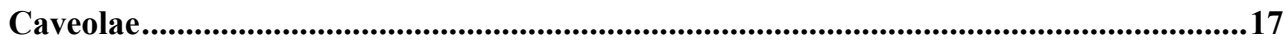

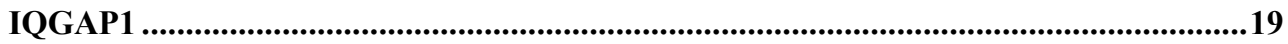

Lipolysis .....................................................................................................................................23

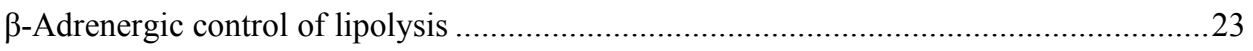

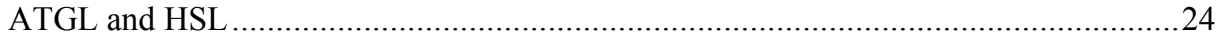

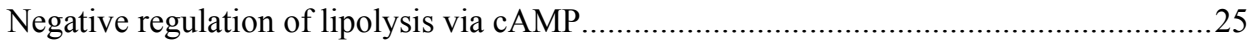

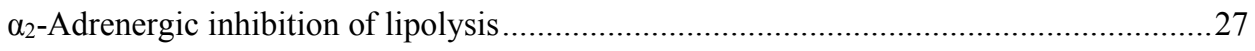

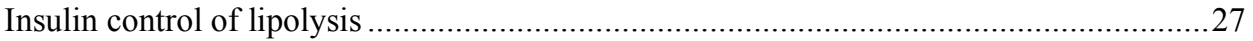

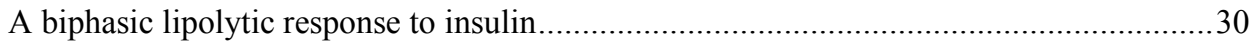

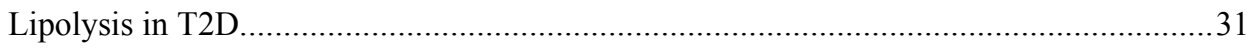

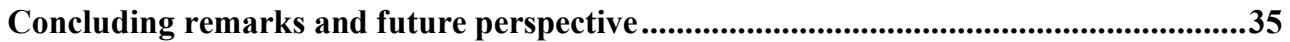




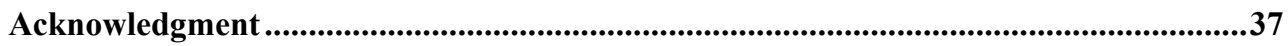

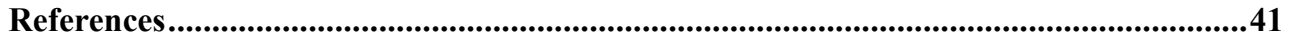




\section{Introduction}

The ability to store energy when food is abundant and to use when supplies are scarce has been essential for survival. But in different parts of the world with unlimited access to food this protective mechanism has become a potentially fatal threat to our health. Obesity is the strongest risk factor for type 2 diabetes (T2D) and with today's sedentary lifestyle the prevalence of obesity is increasing. According to WHO there are 2 billion overweight or obese adults in the world and over 400 million adults suffer from diabetes and the majority of those are type 2 diabetics. T2D is a heterogeneous disease, triggered by both different genetic background and the environment. The development of T2D is often a slow process and it is preceded by insulin resistance in the adipose tissue and later also in muscle and liver. The insulin resistant tissue needs a higher concentration of insulin than healthy tissue to induce the same intracellular response to insulin.

So how and why does the cells become insulin resistant? And how can we prevent this from happening or when it has happened can we reverse it? To answer these questions we need to understand how the insulin signalling pathways function under normal conditions and compare this to the insulin resistant state of diabetes. But the pathways are complex and the complexity is amplified by crosstalk and feedback loops between the involved signalling molecules. A lot of research is being done in this field but there is still much to unravel and the questions remain.

The aim of this thesis is to contribute to the understanding of insulin signalling and insulin resistance in one of the most relevant cell types, mature human adipocytes. In paper I we show that an important feedback mechanism in insulin signalling, the mammalian/mechanistic target of rapamycin in complex with raptor (mTORC1) mediated phosphorylation of insulin receptor substrate 1 (IRS1) on serine 307, is not catalysed by the presumed p70 ribosomal S6 kinase (S6K1) in human primary adipocytes. In paper II we analyse the interactome of the scaffolding protein IQ motif-containing GTPase activating protein-1 (IQGAP1) and how its interaction with caveolae is affected by insulin. We also show that the levels of IQGAP1 are reduced in T2D. In paper III we show that the re-esterification of fatty acids (FA) is reduced in adipocytes from patients with T2D compared to controls, resulting in augmented release of FA, in spite of unaffected lipolysis. We also describe new mechanisms how insulin and isoproterenol signalling interact to control lipolysis via feedback signals. 


\section{The adipose tissue and the adipocyte}

The understanding of adipose tissue has during the last 70 years changed, from being a form of connective tissue and inert lipid store to a major player in energy homeostasis and an endocrine organ. The white adipose tissue is a multi-depot organ and it is mainly distributed in the upper body: subcutaneous, under the skin, and visceral, around vital organs; and in the lower body: subcutaneous around hips and thighs. In healthy humans most of the body's energy reserves are stored in these adipose tissue depots and respond to systemic nutritional needs. There are also smaller depots of adipose tissue in close proximity to other organs that have more distinct and local functions, partially uncoupled from systemic metabolic processes [1]. Adipose tissue associated with skin and intestine can sense and fight bacteria by phagocytosis and release cytokines and antimicrobial peptides. Adipose tissue around the heart provides mechanical and thermal protection and serve as a local supplier of fatty acids, the latter has also been observed for adipose tissue surrounding lactating mammary glands [1].

The main parenchymal cells of the adipose tissue are the adipocytes. Adipocytes are large cells ranging from 20 to over $200 \mu \mathrm{m}$ in diameter. In the adipocyte energy is stored as triacylglycerol (TAG) in a lipid droplet which occupies over $90 \%$ of the cell. The lipid droplet is covered by a layer of phospholipids and protective proteins with only a thin film of cytosol between the droplet and the plasma membrane (Fig. 1). The plasma membrane of adipocytes is rich in caveolae, small flask-shaped invaginations that increase the cell surface area and act as platforms for metabolic signalling and nutrient uptake over the membrane [2].

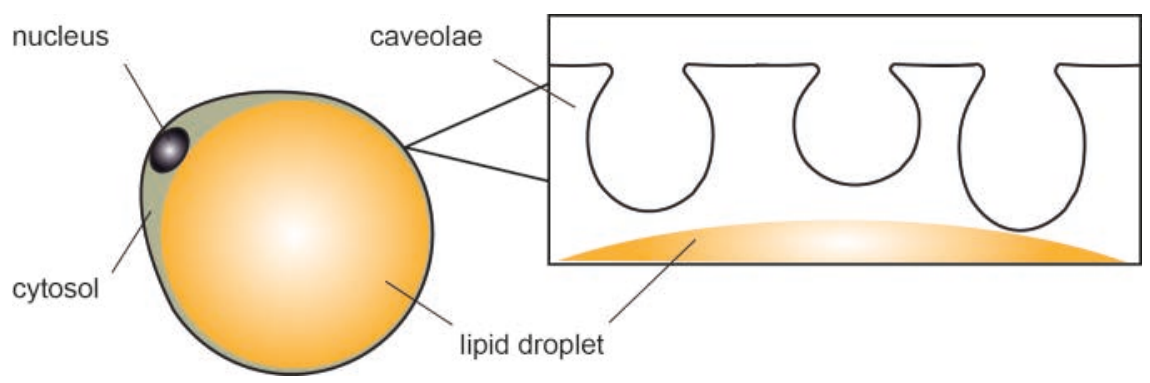

Figure 1. The adipocyte has a large lipid droplet surrounded by a thin film of cytosol. The nucleus protrudes due to the big lipid droplet. One third of the plasma membrane is constituted of cave-like invaginations called caveolae where the insulin receptor is situated.

The adipose tissue has a unique ability to store TAG and expand both through increased cell size (hypertrophy) and increased cell number (hyperplasia). Overeating and too little physical activity cause the adipose tissue to expand, a process that can eventually lead to obesity. There 
is however a limit to how large an adipocyte can get and both increased cell size and an increased number of very small adipocytes have been associated with insulin resistance [3]. Large adipocytes have impaired insulin-induced glucose uptake compared to small adipocytes $[4,5]$. The insulin resistance of large cells could be due to a protective mechanism, preventing over-load and bursting of the adipocyte, which cause cell death and inflammation $[6,7]$. When the adipose tissue is not capable of storing more fat, increased levels of circulating fatty acids will instead be stored ectopically in non-adipose tissues like liver and muscle and there cause insulin resistance [8]. When the tissue becomes insulin resistant, it is less responsive and needs a higher concentration of insulin to be able to take up glucose and maintain the glucose homeostasis. The pancreatic $\beta$-cells adapt to this demand by increasing their mass and to release more insulin. But, eventually high levels of glucose and fatty acids may by various mechanisms lead to $\beta$-cells failing to maintain glucose homeostasis and T2D can be diagnosed $[9,10]$.

Throughout the research reported herein we have examined primary mature human adipocytes, arguably the most relevant cell type for studying mechanisms of the insulin resistance related to T2D. The adipocyte is particularly interesting because the insulin resistance appears to begin in an expanding adipose tissue. To study these cells a biopsy of subcutaneous abdominal adipose tissue is excised during elective surgery on women for diverse gynaecological disorders. The adipose tissue is dispersed by digestion with collagenase to isolate the adipocytes. Using primary cells is advantageous compared to differentiated cells or cell lines since they differ in morphology, which can affect function and signalling. Primary adipocytes have a unilocular lipid droplet whereas differentiated cells have many smaller lipid droplets. An experimental downside with primary cells is the fragility and the buoyancy that comes with the large lipid droplet. Work with primary cells inherently involves a great variability due to the use of cells from different donors, each one with a very different life-style and history. However, the differences that can be distinguished between T2D and a control group most probably reflect general and important dissimilarities. The benefit of cultured cells is the possibility to study long term effect of different stimuli or knock down experiments with siRNA that require longer incubation times, and adipogenic regulation that is not possible in mature primary cells. The use of rodent animal models are common in diabetes research but none of these models comprises all characteristics of human T2D [11]. Different genetically- or dietinduced diabetic mice models have different degrees of obesity, insulin resistance and $\beta$-cell function [12]. In addition the fat pad distribution differ between humans and rodents and also their protein expression profiles [13]. An advantage using mice and rats as animal models for studying the adipose tissue is the possibility for knock out/knock in of specific genes but rodents have the ability to hibernate and have larger depots of brown adipose tissue that makes the interpretation of the results harder to translate to humans. The obvious advantage of using 
human primary mature adipocytes is their physiological, as well as pathophysiological, relevance to humans and to T2D [14].

\section{Glucose homeostasis}

The adipose tissue serves as a short and long term energy reservoir, sugar and lipids are taken up by the adipocytes and stored primarily as TAG when there is an excess of nutrients. When there is a shortage of nutrients, in contrast, the adipose tissue hydrolyses TAG to glycerol and FAs, which are released to the circulation in a process called lipolysis. Together with liver and muscle the adipose tissue controls the glucose homeostasis of the body, keeping the blood glucose levels in a narrow range of 4-10 mM. Homeostasis is maintained by hormonal and nervous control of the adipocyte, hepatocyte and skeletal muscle cells. After a meal, when glucose levels in the blood are increased, the pancreatic $\beta$-cells release insulin into the blood, which increases the glucose uptake in muscle and adipose tissue and decreases the glucose output from the liver. Insulin also stimulates the adipocytes to decrease lipolysis and to increase their fatty acid storage. During fasting, when insulin levels are low and the levels of adrenaline and noradrenaline may be increased, lipolysis will instead be promoted $[15,16]$. 


\section{Insulin signalling in adipocytes}

Insulin signalling in adipocytes starts with the binding of insulin to extracellular domains of the transmembrane insulin receptor (IR). The insulin receptor is situated in the small invaginations of the plasma membrane referred to as caveolae. The receptor auto-phosphorylates to provide binding sites for its intracellular substrates, including the insulin receptor substrate 1 (IRS1). IR then phosphorylates IRS1 on tyrosine residues so that IRS1 can bind and activate the phosphatidylinositol 3-kinase (PI3K). Phosphorylation of tyrosine residues on IRS1 thus propagate the insulin signal reviewed in $[17,18]$. The insulin signal can also be suppressed or enhanced when IRS1 is phosphorylated on certain serine or threonine residues. The binding to tyrosine-phosphorylated IRS1 situates PI3K close to the plasma membrane were it can convert the phospholipid phosphatidylinositol $(4,5)$ bisphosphate (PIP2) to phosphatidylinositol $(3,4,5)$ trisphosphate (PIP3). Production of this phospholipid provides binding sites for protein kinase $\mathrm{B}$ (PKB) and phosphoinositide-dependent kinase-1 (PDK1) that migrate to the plasma membrane where PDK1 can phosphorylate PKB review in [19]. Also the protein kinase mTORC2 (mTOR in complex with rictor) is recruited to the plasma membrane to phosphorylate PKB [20] (Fig. 2). This dual phosphorylation of PKB is needed for full activation of PKB, but relative extent of phosphorylation by PDK1 and mTORC2 appears to target different substrates [21-23].

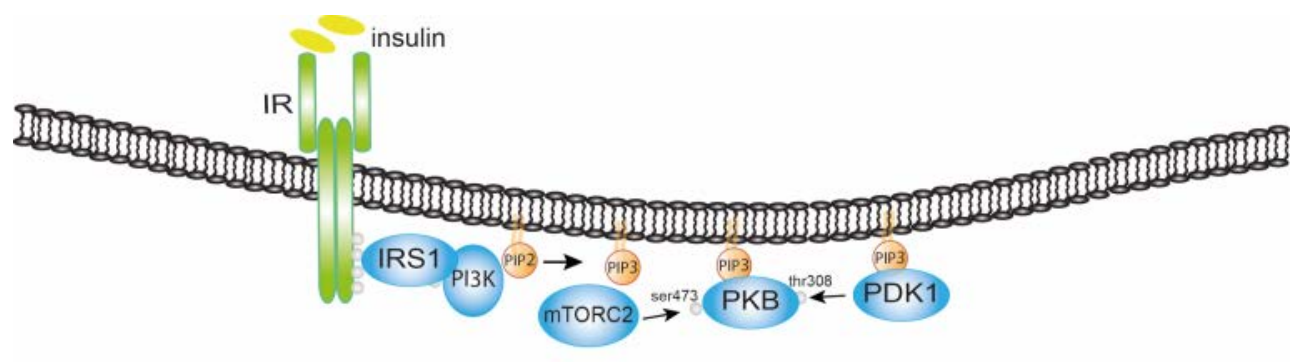

Figure 2. Upon insulin binding the extracellular domains of the IR, IR is autophosphorylated allowing IRS1 to bind to IR. IR then phosphorylates IRS1 creating docking sites for PI3K. PI3K converts PIP2 to PIP3 that will recruit PKB, PDKI and mTORC2 to the plasma membrane. PDK1 can then phosphorylate PKB at Thr308 and mTORC2 phosphorylates PKB at Ser 473 to fully activate $P K B$.

PKB exerts its kinase activity to phosphorylate multiple downstream targets, among them proline-rich AKT1 substrate-1 (PRAS40) and tuberous sclerosis-1 and 2 protein (TSC1/2), and thereby activating mTORC1 [24]. One of the main downstream substrates for mTORC1 is the protein kinase S6K1 that via its substrate ribosomal protein S6 (S6) can control protein 
translation. PKB also phosphorylates glycogen synthase kinase-3 (GSK3) and phosphodiesterase-3B (PDE3B) that will release the inhibition of glycogen synthesis and inhibit lipolysis, respectively. Phosphorylation of the transcription factor forkhead box protein $\mathrm{O} 1$ (FOXO1) will control transcription of specific target genes involved in adaptation to fasting and low insulin, while phosphorylation of Akt substrate of $160 \mathrm{kDa}$ (AS160) will promote translocation of glucose transporter type-4 (GLUT4) to the plasma membrane and increase the uptake of glucose reviewed in [19] (Fig. 3).

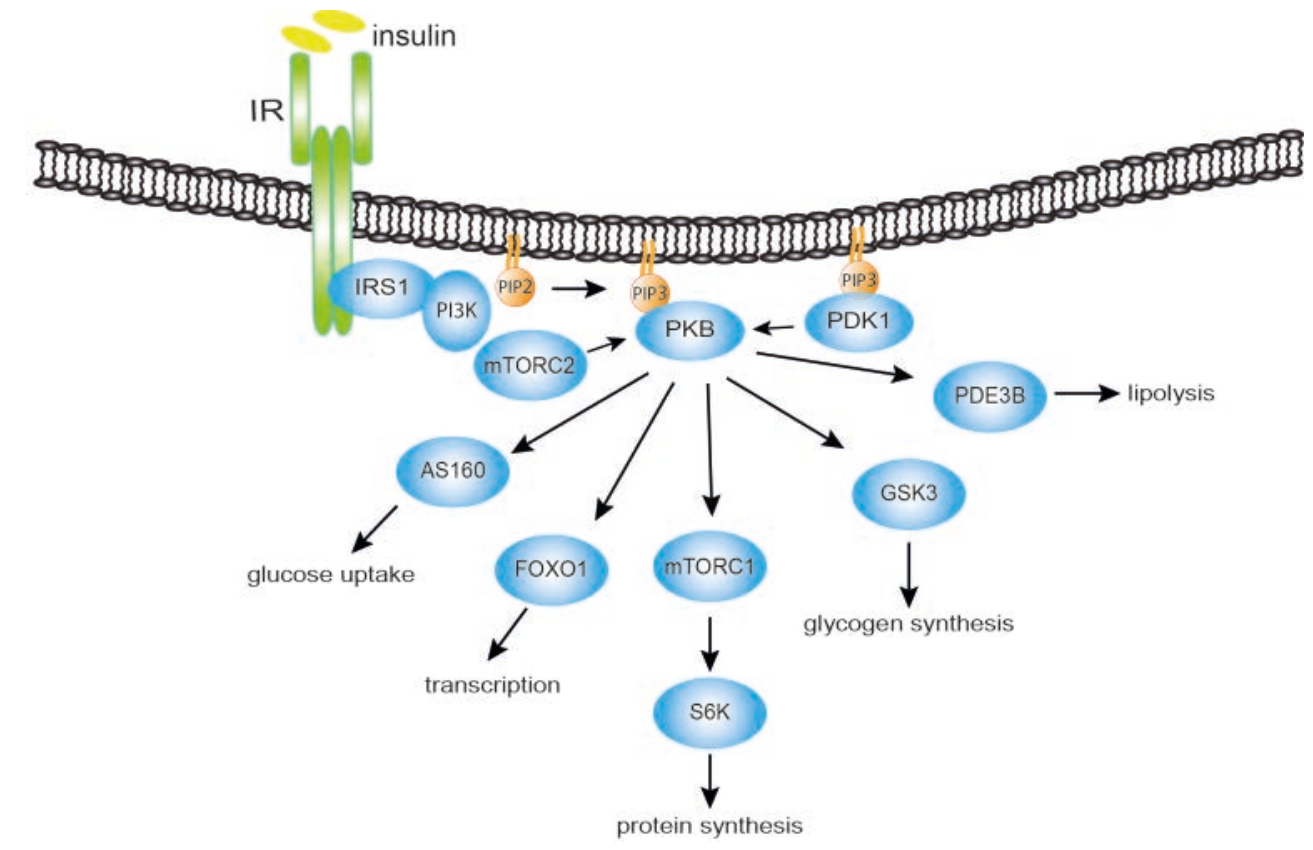

Figure 3. PKB phosphorylates numerous downstream targets to control cellular processes like transcription, protein synthesis, glucose uptake, glycogen synthesis and lipolysis.

\section{Insulin resistance in adipocytes}

\section{Obesity induces insulin resistance}

Obesity is the most common cause of insulin resistance but too little fat can also cause insulin resistance. The importance of a functional adipose tissue that efficiently can store fat is illustrated by lipodystrophy, the loss of adipose tissue, that causes severe insulin resistance and hepatic steatosis [25]. Since adipocytes have a limited capacity to store fat whole body insulin 
resistance may arise from a dysfunctional adipose tissue that no longer can store fat in a proper way. Treatment of T2D with rosiglitazone that increases insulin sensitivity also promotes adipocyte differentiation and weight gain.

Although adipocytes only account for 5-10\% of the total glucose uptake in the body a defect insulin signalling in adipose tissue has a major effect on glucose homeostasis. GLUT4 specific knock out in mouse adipose tissue induces insulin resistance in liver and muscle whereas, with a GLUT4 specific knock out in mouse muscle tissue the animals exhibit normal glucose uptake $[26,27]$. When insulin signalling in adipocytes was enhanced with an adipose tissue specific deletion of a protein phosphatase, the animals greatly expanded their adipose tissue on a high fat diet, but were protected from diet-induced hepatic steatosis and had improved insulin singling in the liver compared to wild type (wt) animals [28]. Taken together, this indicates that the adipose tissue likely is the origin of whole body insulin resistance connected to obesity [29].

\section{Selective insulin resistance}

That insulin-stimulated glucose uptake is impaired in the insulin-resistant state is well established and this is often what is meant when referring to insulin resistance. However, not all branches of the insulin signalling network seem to be effected in the insulin resistant state. As shown in insulin resistant liver cells, the insulin induced suppression of glucose production was impaired while the insulin induced fatty acid synthesis was unaffected [30, 31]. Selective insulin resistance has also been suggested in adipose tissue, in insulin resistant 3T3-L1 cells and mouse models, where phosphorylation of PKB and glucose uptake was reduced in all models but anti-lipolysis and protein synthesis where unaffected [32].

Results from my research group have shown that adipocytes from T2D patients have reduced insulin sensitivity for phosphorylation of extracellular signal-regulated kinase (ERK), AS160, and IRS1 at tyrosine residues and at serine 307 (Ser307), reduced glucose uptake, and impaired signalling downstream mTORC1 compared to adipocytes from control subjects; while the sensitivity for insulin stimulated phosphorylation of PKB and FOXO1 is unaffected in T2D [21, $33,34]$. In paper III we also show that the inhibitory effect of insulin on isoproterenolstimulated lipolysis is not affected in the adipocytes from T2D patients compared to control subjects.

\section{The role of IRS1 in insulin signalling}

Unlike most other receptor tyrosine kinases (RTK), which bind directly to their cytoplasmic effectors, the IR mainly works through adaptor proteins, where IRS proteins are one of the most 
critical nodes for insulin signalling. IRSs bind to IR at phosphorylated tyrosine, via its phosphotyrosine binding (PTB) domain and pleckstrin-homology (PH) domain, and are thereafter phosphorylated by IR on multiple tyrosine residues. This in turn creates docking sites on IRSs for proteins containing a Src Homology 2 (SH2) domain. There are three different IRS isoforms expressed in humans. IRS1 and IRS2 are expressed in various tissues including the insulin sensitive adipose, muscle and liver tissues, whereas IRS4 is expressed mainly in the hypothalamus [35]. IRS1 is the main IRS for insulin stimulated glucose uptake in adipose and muscle tissue while in liver tissue IRS1 and IRS2 have overlapping roles [36, 37].

\section{Phosphorylation of IRS1}

Phosphorylation of IRS1 at tyrosine residues transmits the insulin signal, while additional feedback signals to serine and threonine phosphorylation of IRS1 can either enhance or reduce the insulin signal. Mass spectrometry analyses have revealed the phosphorylation of more than $50 \mathrm{Ser} / \mathrm{Thr}$ residues that respond to insulin stimulation. Several of these have been extensively examined with the use of for example specific antibodies or IRS1 mutants. Ser307 is one of the most studied phospho-sites but results are contradictory both regarding its impact on insulin signalling and the protein kinases responsible for the phosphorylation.

Results from our research group have showed that in human adipocytes the phosphorylation of IRS1 at Ser307 is increased upon insulin stimulation and appears to act as a positive feedback to increase insulin signalling [34]. The Ser307 phosphorylation was sensitive to inhibition of mTORC1 with rapamycin. Rapamycin decreased the phosphorylation of Ser307 in response to insulin as well as the insulin sensitivity for phosphorylation of IRS1 at tyrosine residues (using the phospho-tyrosine specific antibody PY20) and downstream signalling to ERK [33, 34]. We have also found that the phosphorylation of Ser307 in response to insulin is attenuated in adipocytes from T2D patients [34].

A positive effect on insulin signalling by the phosphorylation of IRS1 at Ser307 has also been shown in muscle cell lines [38]. With gain- and loss-of-function mutants, rapid phosphorylation of Ser307 and Ser323 was followed by a slower but more prolonged Ser312 phosphorylation that sequentially first stimulated and then inhibited IRS1 signalling [38]. Substituting S307A in rat-IRS1, in cell lines, also resulted in decreased tyrosine phosphorylation of IRS1 and reduced signalling downstream of mTORC1, but without effect on insulin-stimulated phosphorylation of PKB at Ser473 [39]. Phosphorylation of IRS1 at Ser307 was mediated by mTORC1 as it was inhibited with rapamycin in this study [39]. The opposite effect has been reported with the dual phosphorylation of IRS at Ser307 and Ser312 that, in a yeast-two hybrid experiment, disrupted the interaction between IR and IRS1 and where phosphorylation at both Ser307 and Ser312 was 
increased in mouse models of insulin resistance and obesity [40]. However, recently published data showed that the insulin induced phosphorylation of IRS1 at Ser307 in mouse liver and muscle had no effect on glucose homeostasis or insulin signalling in the animal, and that activation of mTORC1 by TSC1-deletion did not increase the phosphorylation at Ser307 [41].

Although a few reports state that IRS1 can be phosphorylated at Ser307 by JNK [40], PKC $\delta$ [42] or PKB [43], the general view is that the phosphorylation is downstream of mTORC1. S6K1 has been shown to phosphorylate Ser307 in vitro and in S6K1 knock out experiments the phosphorylation of IRS1 at Ser307 is reduced compared to wt [44, 45]. To examine if this was also the case in human adipocytes, we created a dominant negative (DN) construct of S6K1 and in parallel used an inhibitor of S6K1 (Paper I). Neither DN-S6K1 nor S6K1-inhibition had any effect on the insulin-stimulated phosphorylation of IRS1 at Ser307 even though they both inhibited phosphorylation of the S6K1 specific downstream target S6. These data together with the very different time-courses, where the phosphorylation of Ser307 reaches a quasi-steady state after 5 min of insulin stimulation, whereas phosphorylation of S6K1 at Thr389 and S6 at Ser235/236 have very slow onset of phosphorylation and do not reach a quasi-steady state until after $30 \mathrm{~min}$ of insulin stimulation, make it unlikely that S6K1 is the endogenous kinase for phosphorylation of IRS1-Ser307 in human adipocytes.

We also immunoprecipitated mTOR from insulin-stimulated adipocytes and showed in an in vitro kinase assay that this precipitate phosphorylated an IRS1 derived peptide on Ser307. The peptide spanned IRS from amino acid 288 to 314 and, as detected with LC-MS/MS, Ser307 was the only amino acid phosphorylated in this peptide. Moreover a S307A substituted peptide was not phosphorylated. Addition of an mTOR inhibitor to the kinase assay did not affect this phosphorylation and S6K1 inhibition had a small but not significant effect. Together the two inhibitors decreased the phosphorylation by $30 \%$, allowing us to conclude that S6K1 can phosphorylate Ser307 in vitro but it is not the main Ser307 kinase in the precipitate. This yet unidentified protein kinase activity may be responsible for the endogenous phosphorylation of IRS at Ser307 in human adipocytes.

Due to the numerous serine and threonine phosphorylation sites in IRS1, which are affected upon insulin stimulation, it is likely that the pattern and the temporal changes of the phosphorylation are more important than the phosphorylation at any single phospho-site, and that these can be different in different cell types. Also signalling via different phospho-tyrosine residues might be differently affected by Ser/Thr phosphorylation at different locations in IRS1 to activate or inhibit the activity of different downstream targets. This issue deserves further investigation. However, our results indicate that the phosphorylation of IRS1 at Ser307 is involved in and in a positive way contributes to the insulin signalling in human adipocytes. 
Moreover the responsible protein kinase is activated downstream of mTORC1, but it is neither mTOR itself nor S6K1.

\section{PI3Ks in signalling transduction}

Phosphatidylinositol is a membrane phospholipid that in mammals can be phosphorylated at three (position 3, 4 and 5) of the five free hydroxyl groups of its inositol ring. The phosphorylated forms of phosphatidylinositols, the phosphoinositides, act as second messengers regulating different cellular functions. PI3Ks are members of a lipid kinase family that adds a phosphate group to the third position of the inositol ring. There are three classes of PI3K, class I, II and III (reviewed in [46-49]). Class I phosphorylates phosphatidylinositol- 4, 5 phosphate (PIP2) to generate phosphatidylinositol-3, 4, 5 phosphate (PIP3), one of the most important phosphoinositides. Class II produces phosphatidylinositol-3 phosphate and phosphatidylinositol-3, 4 phosphate and class III produces phosphatidylinositol-3 phosphate.

\section{Class I PI3Ks}

The class I PI3K functions as a heterodimer of one regulatory and one catalytic subunit. There are four different catalytic subunits $\mathrm{p} 110 \alpha, \beta, \gamma$ and $\delta$ and several regulatory subunits. The $\mathrm{p} 110 \alpha$ and $\beta$ are widely expressed whereas $\mathrm{p} 110 \gamma$ and $\delta$ are considered to be limited to immune cells, though it has been shown that $\mathrm{p} 110 \gamma$ is expressed to some degree also in other tissues including adipocytes of mice [50].

PI3K in complex with $p 110 \alpha$ catalytic subunit is the most studied form and the most important PI3K for transducing the signal from RTKs, such as the IR. p110 $\alpha$ knock out mice are embryonically lethal and heterozygotes are hyperinsulinemic and glucose intolerant, demonstrating the importance of $\mathrm{p} 110 \alpha$ in cell signalling. P110 $\alpha$ forms a dimer with the regulatory $\mathrm{p} 85 \alpha$, which contains $\mathrm{SH} 2$ domains that recognise tyrosine phosphorylated motifs on either the RTK or its docking protein, like IRS1 [51]. Upon binding to phospho-tyrosine p $85 \alpha$ releases its inhibitory effect on $\mathrm{p} 110 \alpha$, which can catalyse the phosphorylation of PIP2 to PIP3.

P110 $\beta$ forms a complex with $p 85 \beta$ and this PI3K $\beta$ can be activated by G-protein coupled receptors (GPCR) through the G-protein subunit $\mathrm{G}_{\beta \gamma}$. Also RTK can activate PI3K $\beta$, but not to the same extent as PI3K $\alpha$ [47]. PI3K $\beta$ knock out mice are like the PI3K $\alpha$ knock outs embryonically lethal, but mice expressing kinase dead PI3K $\beta$ survive to adulthood although they develop mild insulin resistance. This shows that PI3K $\beta$ exhibits both kinase-dependent and kinase-independent functions. In liver from kinase dead PI3K $\beta$ expressing mice insulin 
induces normal phosphorylation of PKB for $5 \mathrm{~min}$ of stimulation, but thereafter the phosphorylation declines much faster than for wt, suggesting that $\operatorname{PI} 3 \mathrm{~K} \beta$ catalytic activity is important for a sustained insulin signal [52].

p1 $10 \delta$ together with $\mathrm{p} 85 \alpha$ or $\beta$ acts downstream of RTKs in immune cells. The p110 $\gamma$ catalytic subunit together with regulatory p101 is activated by $\mathrm{G}_{\beta \gamma}$. In addition to its lipid kinase activity PI3K $\gamma$ also possesses protein kinase activity and kinase-independent functions as a scaffold protein. All of the class I PI3K also contain a Ras-binding domain and can be activated by Ras. PI3K class I generated PIP3 recruits proteins containing a PH domain to the plasma membrane for signal transduction. The $\mathrm{PH}$ domain is arranged like a pocket with basic amino acids where the inositol head group of PIP3 fits and is electrostatically attracted [53].

\section{Class II and III PI3Ks}

The class II PI3K family consists of three large monomeric proteins PI3KC2 $\alpha, \beta$ and $\gamma$, where $\alpha$ and $\beta$ are expressed broadly and $\gamma$ mainly in the liver [47]. The class II PI3Ks are less studied than class I PI3Ks and there are no known adaptor proteins for class II PI3K, neither do they have a regulatory subunit. But different studies suggest that they can be activated downstream RTK and GPCR, and also via mechanisms distinct from class I PI3K, reviewed in [54]. $\mathrm{PI} 3 \mathrm{KC} 2 \alpha$ has been implicated, for example, in insulin secretion from $\beta$-cells $[55,56]$ and in GLUT4 translocation. Downregulation of PI3KC2 $\alpha$ in muscle cells partially inhibited GLUT4 translocation to the plasma membrane and reduced the glucose uptake [57]. Kinase dead $\mathrm{PI} 3 \mathrm{KC} 2 \beta$ has on the other hand been shown to improve glucose tolerance in mice where inactivated PI3KC2 $\beta$ increased PKB activation in liver, muscle and adipose tissue compared to wt [58]. There is only one known class III PI3K, hVps34 and its known biological function in mammals so far is within vesicle trafficking. PI3Ks class II and III are less sensitive to the widely used PI3K inhibitor wortmannin than class I PI3Ks are.

\section{PKB - a regulatory hub}

$\mathrm{PKB}$, also referred to as Akt, is a pivotal protein kinase involved in the control of many cellular processes including metabolism and cell proliferation. Over 100 substrates of PKB have been described. Although, not all of them are verified, this demonstrates the impact PKB has in multiple signalling networks. In the insulin signalling network PKB forms a hub for the control of different downstream signalling pathways as well as receiving input from different upstream pathways. 
There are three different isoforms of $\mathrm{PKB}: \mathrm{PKB} \alpha, \beta$, and $\gamma$ and the expression is tissue specific. $\mathrm{PKB} \alpha$ is ubiquitously expressed, $\mathrm{PKB} \beta$ is mostly expressed in insulin sensitive tissues and $\mathrm{PKB} \gamma$ is primarily expressed in the brain. Tissue specific deletion of both $\mathrm{PKB} \alpha$ and $\beta$ in adipocytes in mice caused severe lipodystrophy in the animals, with no observable subcutaneous adipose tissue, and the mice developed insulin resistance [59]. In mouse adipocytes $\mathrm{PKB} \beta$ has been described as the most important isoform [60]. In human adipocytes it has been shown that $\mathrm{PKB} \beta$ is indispensable for adipogenesis but both $\mathrm{PKB} \alpha$ and $\beta$ are important for insulin signalling in mature adipocytes as measured by suppression of lipolysis, glucose uptake and lipogenesis [61].

\section{Phosphorylation of PKB}

The activation of PKB is dependent on the phosphorylation of Ser473 by mTORC2 and Thr308 by PDK1. PKB and PDK1 both harbours a PH domain that are recruited to the plasma membrane upon RTK or GPCR stimulated generation of PIP3. When the PH domain of PKB is bound to PIP3 a conformational change is induced, which gives PDK1 access to phosphorylate PKB. It has been suggested that also mTORC2 is recruited to the plasma membrane via the $\mathrm{PH}$ domain of the subunit mSIN1, thus releasing an autoinhibition of mTORC2 and thereby promoting the phosphorylation of PKB by mTORC2 [20]. Phosphorylation of both Ser473 and Thr308 is required for full activation of PKB [62]. Contradictory results have been reported, whether phosphorylation of one of the sites affects the phosphorylation of the other one or not. Some studies show that the phosphorylation of PKB at Ser473 facilitates a subsequent phosphorylation at Thr308 [63, 64]. The opposite has also been shown where phosphorylation of PKB at Thr308 precedes and promotes the phosphorylation of Ser473 via a positive feedback. The phosphorylation of PKB at Thr308 by PDK1 activates PKB to phosphorylate the mTORC2 component mSIN1, which enhances the activity of mTORC2 that in its turn phosphorylates PKB at Ser473 [65].

Full activation of PKB might not be needed for all substrates and either of the two phosphorylation sites might be enough to selectively trigger stimulation of specific downstream substrates. In mouse embryos and embryonic fibroblasts deletion of rictor or the mammalian lethal with SEC13 protein 8 (mLST8) suppressed basal and insulin induced phosphorylation of $\mathrm{PKB}$ at Ser473 but did not have a major effect on the phosphorylation at Thr308 [22]. This resulted in reduced phosphorylation of the PKB-downstream targets FOXO3 and PKC $\alpha$, but not GSK3, TSC2 and S6K1 [22]. Deletion of the mTORC2 specific component mSIN1 in mouse embryonic fibroblasts resulted in insulin induced phosphorylation of PKB at Thr308 but not at Ser473 [23]. mSIN1 ablation, as for the rictor and mLST8 depletion, did not affect all downstream targets of $\mathrm{PKB}$, so that phosphorylation of FOXO1/3a was reduced whereas the 
phosphorylation of GSK3, TSC2, S6K1 and eukaryotic translation initiation factor 4E-binding protein-1 (4EBP1) was not affected compared to wt cell [23]. In human adipocytes the inhibition of mTOR and thereby inhibition of phosphorylation of PKB at Ser473 abolished the insulin-stimulated phosphorylation of FOXO1 [21]. In paper III we find that isoproterenol can stimulate the phosphorylation of PKB at Ser473 and thereby induce an anti-lipolytic effect that is inhibited by mTOR inhibition.

\section{mTORC1 and mTORC2}

The serine/threonine protein kinase mTOR is the catalytic subunit of two discrete protein complexes, mTORC1 and mTORC2, that are important coordinators of cell growth and metabolism (Fig. 4). In addition to mTOR the two complexes also have the two subunits DEP domain-containing mTOR-interacting protein (DEPTOR) and mLST8 in common. DEPTOR is a regulatory subunit that interacts with mTOR and inhibit its kinase activity and mLST8 is suggested to stabilise the kinase domain $[66,67]$. The unique subunits of $\mathrm{mTORC} 1$ are raptor and PRAS40. PRAS40 binds to raptor and functions as an inhibitor of mTOR. Raptor stabilises mTORC1 and acts as a scaffold protein, regulating the substrate specificity via binding of substrates containing TOR signalling (TOS) motifs. The distinct subunits of mTORC2 are rictor, $\mathrm{mSIN} 1$ and protor $1 / 2$, where rictor is thought to have similar function as raptor has in $\mathrm{mTORC} 1$, and $\mathrm{mSIN} 1$ and protor $1 / 2$ are regulatory proteins. $\mathrm{mSIN} 1$ has been shown to be essential for the phosphorylation of PKB downstream of mTORC2 [68].

mTORC1

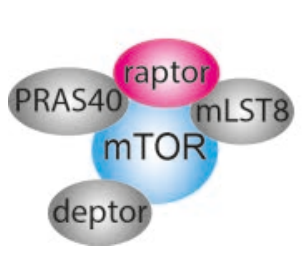

mTORC2

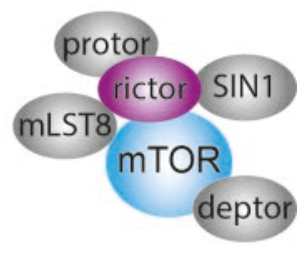

Figure 4. Schematic views over the subunits of the two mTOR containing complexes.

mTORC1 is a nutrient sensing complex that controls anabolic processes in the cell, it can be activated directly by nutrients like amino acids and glucose [69] but also indirectly via growth factor signalling, e.g. insulin signalling. The activation of $\mathrm{mTORC1}$ by insulin requires phosphorylation and inactivation of the TSC1/2 complex by PKB. The TSC1/2 complex is a 
GTPase activating protein that converts its only known substrate the GTP-binding protein Rheb to its inactive form by hydrolysis of the Rheb-bound GTP to GDP. Inactivation of TSC1/2 complex by the PKB phosphorylation allows the active Rheb-GTP to activate mTORC1 through a direct interaction with the catalytic domain of mTOR as well as with mLST8 and raptor [70]. PKB and activated mTOR then phosphorylate PRAS40 and this causes PRAS40 to dissociate from mTORC1. PRAS40 that was bound to raptor via its TOS-motif, can now make room for other TOS-motif containing substrates. mTOR also phosphorylates DEPTOR causing its dissociation from the complex [67].

Two proteins important for protein synthesis lie downstream of mTORC1, the S6K1 and 4EBP1. They both contain a TOS-motif that binds to raptor for subsequent phosphorylation by mTOR at Thr389 of S6K1 and Thr37 and Thr46 of 4EBP1 [71]. For full activation S6K1 also needs to be phosphorylated by PDK1 on Thr229 after which S6K1 then phosphorylates several substrates that stimulate the mRNA translation initiation [72]. Phosphorylation of 4EBP1 leads to the release of its inhibitory effect on translation [73]. MEFs and 3T3-L1 preadipocytes that lack the TSC1/2 complex, and therefore have constitutively active mTORC1, exhibit enhanced adipocyte differentiation due to increased expression of PPAR $\gamma$, an important transcription factor for genes involved in adipogenesis and glucose homeostasis [74]. How mTORC1 control the expression of PPAR $\gamma$ is however not known [75]. In S6K1-deficient mice on high fat diet the adipocytes expand in size, but not in number, compared to wt, which was suggested to be a result of reduced levels of transcription factors involved in early adipocyte differentiation e.g. $\mathrm{C} / \mathrm{EBP} \beta$, and $\mathrm{C} / \mathrm{EBP} \delta$ [76]. Upon insulin activation of mTORC1 also upstream regulators of this complex are affected by positive or negative feedback loops from mTORC1, such as the phosphorylation of IRS1 at Ser307.

mTORC2 is mainly activated by insulin in a PI3K dependent way, but also lipids can regulate the mTORC2 activity [77]. How PI3K activates mTORC2 is not fully understood, but PI3K has been found to promote association of ribosomes with mTORC2 for activation of the kinase and PIP3 generated from PI3K induces mSIN1 to release its inhibitory effect on mTORC2 [20, 78]. The major downstream substrate for mTORC2 is PKB, which is phosphorylated at Ser473. mTORC2 also co-translatory phosphorylates PKB at residue Thr450 for proper folding and stability of the protein during translation [79]. It has been shown that mTORC2 can phosphorylate PKB at Ser477/Thr479 in response to insulin and the authors suggest that this initiates the activation of PKB by either locking PKB in an active form or by promoting the association of mTORC2 with PKB and thereby the phosphorylation of Ser473 [80]. Activated PKB phosphorylates multiple targets including mTORC1, FOXO1, AS160 and GSK3, thereby affecting translation, transcription, glucose uptake and glycogen synthesis, respectively. 
Moreover mTORC2 has been shown to be regulated by mTORC1. Insulin stimulation induces a feedback via mTORC1 and S6K1 that phosphorylates rictor in a rapamycin-sensitive manner, there is however conflicting results regarding the downstream effects of this phosphorylation [81-83].

Knock out animals lacking raptor or rictor are embryonically lethal. Therefore inducible knock outs, in mature adipocytes with adiponectin-cre, has been used to evaluate the contribution of the two subunits in adipocyte growth and function [84, 85], described below. In raptor knock out animals the adipose tissue does not properly expand on a high fat diet and fat is instead accumulated in the liver. Likewise, the rictor knock out animals are incapable of expanding their adipose tissue on a high fat diet with increased accumulation of TAG in the liver. The rictor knock out animals also accumulate fat in the heart, in contrast to raptor knock outs. Isoproterenol induced lipolysis and phosphorylation of HSL was not affected in either of the knock out models. However, in rictor knock out animals insulin could not suppress elevated plasma levels of FA after fasting (the insulin-effect on lipolysis was not measured in raptor knock out animals). Data from raptor knock out animals suggest that mTORC1 is important for adipose tissue expansion via $\mathrm{C} / \mathrm{EBP} \alpha$, a co-regulator of $\operatorname{PPAR} \gamma$, which is greatly reduced when raptor is knocked out [84]. Deletion of rictor, with reduced levels of the transcription factor ChREBP $\beta$, suggests that mTORC2 is important for adipose tissue expansion via the expression of ChREBP $\beta$ and thereby increased de novo lipogenesis [85].

Rapamycin is a specific inhibitor of mTORC1 and has been an important tool in trying to elucidate the role of mTORC1 in adipocytes. Together with FKBP12 rapamycin binds to mTOR and sterically hinder the access to raptor by the substrates and thereby inhibits the downstream signal [86]. Rapamycin does not acutely inhibit mTORC2, but prolonged treatment with rapamycin has been shown in rodents to limit the access of mTOR for synthesis of mTORC2. Even though rapamycin is a highly specific inhibitor of mTORC1, and doesn't inhibit other kinases, it does not fully inhibit the phosphorylation of all mTORC1 downstream targets [87]. mTORC1 is important for adipocyte differentiation, similar to raptor knock out rapamycin inhibits adipogenesis of mouse and also human pre-adipocytes [88, 89]. Regarding the more acute effects of rapamycin on insulin signalling and glucose uptake the results are more inconsistent both in 3T3-L1 cells and human adipocytes, short term treatment with rapamycin has been shown increase, decrease or not significantly affect the insulin stimulated glucose uptake [89-92]. Long term treatment with rapamycin is harder to use for evaluation of mTORC1 actions since the inhibitor then also can affect mTORC2, although that does not appear to happen in primary human adipocytes [21]. 


\section{Caveolae}

In adipocytes almost all IRs are situated in the caveolae with multiple IR per caveola [93]. Caveolae are cholesterol rich lipid rafts that together with structural proteins form small invaginations with 60-80 $\mathrm{nm}$ in diameter in the plasma membrane. Caveolae are expressed in various tissues including adipocytes where one third of the plasma membrane is constituted of caveolae [94]. They are involved in endocytosis and they provide functional platforms for signal transduction and metabolic processes. A certain level of cholesterol is needed for the caveolae to form and depletion of cholesterol destroys the caveolae structures [95]. There are also three proteins essential for the formation of caveolae, caveolin-1, cavin-1 (also called polymerase I and transcript release factor (PTRF)) and cavin-2, when either of these proteins are knocked out in mice caveolae will not be formed in adipocytes [96]. Cavin-3 is not central for the caveolae formation but involved in the endocytosis of caveolar vesicles [97]. Caveolae are highly detergent resistant, which make these domains of the plasma membrane ideal for uptake and probably release of the large amounts of FA transported over the adipocyte membrane [98]. When the FA has passed the membrane, in a specific subset of caveolae containing triacylglycerol synthesizing enzymes and perilipin, FAs are converted into TAG [99].

After insulin has bound to IR the receptor phosphorylates caveolin-1 and is rapidly endocytosed in a caveolae-dependent process [100]. In human adipocytes IRS1 co-localises with IR and caveolae even under non-insulin-stimulated conditions [101]. Depletion of cholesterol in human adipocytes inhibits insulin signalling downstream of IRS1 [95]. When caveolin-1 or cavin-1 was knocked out in rodents the IR levels were reduced due to enhanced degradation of IR [93]. Also GLUT4 has been found, but not exclusively, in caveolae in mouse and human adipocytes and there are reports of both caveolae- and clathrin-mediated endocytosis of GLUT4 [93]. The trafficking of caveolae from and to the cell membrane is navigated and powered by microtubule and actin filaments and caveolin- 1 can bind to filamin associated to actin $[97,102$, $103]$. 


\section{IQGAP1}

Similar to caveolae, scaffolding proteins that assemble multiple proteins in close proximity to each other can regulate the speed, specificity and localization of signalling pathways. IQGAPs are large scaffolding proteins that exist as three isoforms IQGAP1, 2, and 3. The distribution of IQGAP2 and 3 are more limited to specific tissues and they are less studied than the best characterised isoform IQGAP1, which has a broad tissue distribution [104]. IQGAP1 with a molecular mass of $195 \mathrm{kDa}$ comprises several protein domains: a calponin-homology domain (CHD), putative coil-coil homodimerisation domains, a tryptophane repeat motif (WW), 4 IQmotifs, a Ras GTPase-activating domain (GRD), and a RasGAP terminus domain (RGCt) [105] (Fig. 5). The many binding motifs reflect that more than 100 unique IQGAP1-interacting proteins have been described and implicated in diverse cellular functions. IQGAP1 has for example been implicated in cytoskeletal dynamics, cell proliferation, vesicle trafficking and intracellular signalling [104, 106].

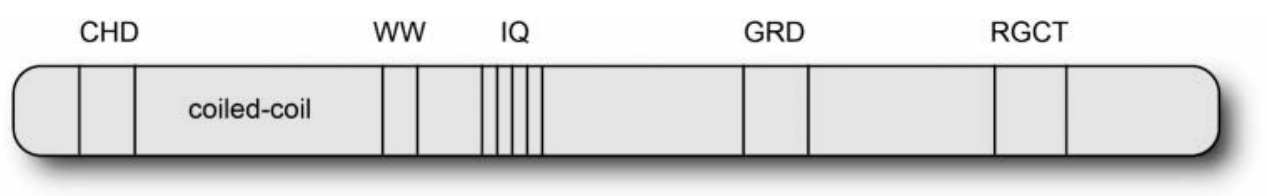

Figure 5. Schematic view over IQGAPI domains: calponin-homology domain (CHD), putative coil-coil homodimerisation domains, a tryptophane repeat motif $(W W), 4$ IQ-motifs, a Ras GTPase-activating domain (GRD), and a RasGAP terminus domain (RGCt).

Upregulated expression of IQGAP1 has been demonstrated in several cancer cell-lines and in various tumour tissue samples [107]. Several of the proteins reported to interact with IQGAP1 are proteins involved in cell proliferation and thereby common to signalling dysfunctions in both cancer and T2D. In HeLa and NIH3T3 cells, stably expressing different IQGAP1constructs, IQGAP1 co-precipitated with raptor [108] and the IQ-motifs have been shown to bind ERK1/2 [109]. In rat aorta cells IQGAP1 was required for activation of ERK1/2 bound to actin and caveolin-1 was needed for actin-bound ERK1/2 to be phosphorylated by PKC, suggesting that IQGAP1 and caveolin-1 are both needed for PKC-mediated ERK-activation [110].

In paper II we report for the first time the presence and a role for IQGAP1 in human adipocytes. We demonstrate that both the protein and mRNA levels are reduced in adipocytes from T2D subjects compared to adipocytes from control subjects, which suggests a deficiency at the transcriptional level in the diabetic state. In kidney tissue biopsies from patients diagnosed with 
T2D and diabetic kidney disease IQGAP1 mRNA levels were decreased compared to control tissue [111]. In cultured podocytes treatment with high glucose reduced both IQGAP1 mRNA and protein levels that could be rescued with pre-incubation with an ERK-inhibitor [111].

In paper II we also performed immunoprecipitation of IQGAP1 for subsequent analysis of its interactome in human adipocytes with mass spectrometry. In addition to cytoskeletal proteins we also found the caveolae-associated proteins caveolin-1, cavin1-3 and EH domain-containing protein 2 (EHD2), and proteins involved in TAG synthesis hormone sensitive lipase (HSL), perilipin1 (PLIN1), perilipin4 (PLIN4) and fatty acid synthase (FASN).

With a proximity ligation assay (PLA) two proteins that co-localise, separated by less than 40 $\mathrm{nm}$, in situ can be detected and visualised. Antibodies conjugated to a short DNA strand can, if the DNA strands are close enough, be used as a template for DNA amplification. With addition of fluorescent probes, which hybridise to the amplified DNA, a strong signal is detected if the proteins are in close proximity to each other [112]. With this PLA technique we demonstrated co-localization of IQGAP1 and caveolin-1. We also found that the co-localization increased five-fold in the response to insulin (paper II) (Fig. 6).
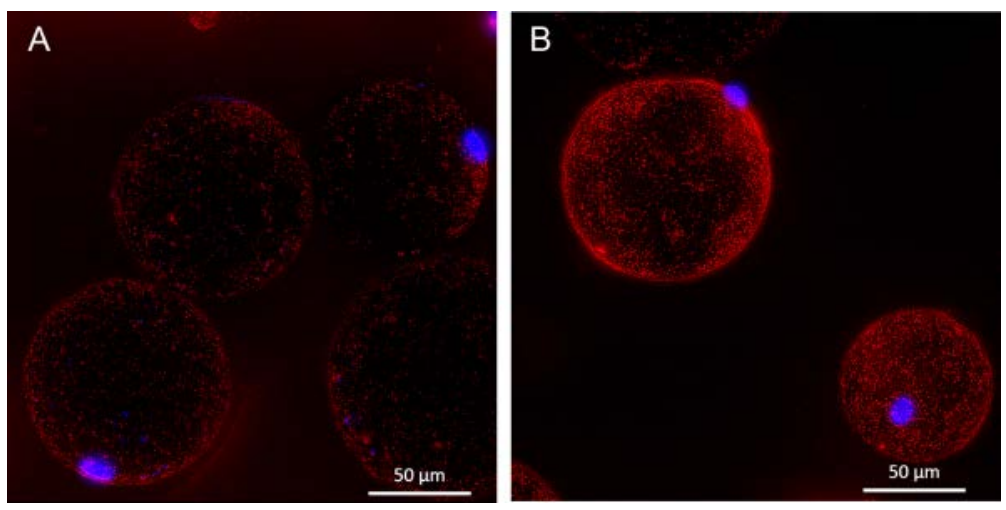

Figure 6. Fluorescence microscopic images demonstrating the insulin-dependent association of caveolin-1 and IQGAP1. (A) Co-localization of IQGAPI and caveolin-1 under basal conditions. (B) Co-localization of IQGAPI and caveolin-1 after stimulation with insulin.

Thus, we propose that IQGAP1 provides an insulin-regulated link between the cytoskeleton and caveolae in human adipocytes and that IQGAP1 might be involved in the insulin induced endocytosis and recycling of IR. IR is situated in caveolae and endocytosed in a caveolaemediated process and caveolar trafficking requires involvement of the cytoskeleton [102]. IQGAP1 is reported to interact and regulate cytoskeletal components [105] and has been implicated in exocytosis of insulin [113] and endocytosis of vesicles in $\beta$-cells [114]. IQGAP1 
has also been demonstrated to be involved in the transport and insertion of caveolae into the plasma membrane by stabilizing microtubules [115].

Recently two articles have proposed IQGAP1 to be highly involved in insulin signalling. Using various cancer cell-lines it was shown that upon agonist stimulation IQGAP1 binds all the phosphoinositide kinases needed for sequential phosphorylation of phosphatidylinositol to PIP3, including PI3K, as well as the downstream substrates of PI3K: PKB and PDK1 [116]. Moreover the insulin-induced phosphorylation of PKB was reduced in liver and muscle tissue of IQGAP1 knock out animals compared to wt [116]. In different cell lines, IQGAP1 was shown to interact with IR via its IQ domains, and the PTB domain of IRS1 to interact with the RGCT domain of IQGAP1 [117]. The absence of IQGAP1 in MEFs impaired insulin signalling downstream of IRS1 where the IRS1-PI3K interaction was reduced, as well as the phosphorylation of ERK and PKB [117]. IQGAP1 knock out animals were glucose intolerant and the phosphorylation of PKB was reduced in muscle, liver and adipose tissue compared to wt animals [117]. These results together with our findings support the idea of IQGAP1 as an important player in insulin signal transduction via caveolae. 


\section{Lipolysis}

\section{$\beta$-Adrenergic control of lipolysis}

Lipolysis is the process where a TAG is hydrolysed by lipases to generate one glycerol molecule and three fatty acid molecules. There is a very limited reuse of glycerol in adipocytes because of lack of the enzyme glycerol kinase (GyK), however, FA are readily recycled and the ratio of released glycerol:FA therefore varies. For these reasons the glycerol release from adipocytes is used as a measurement of intracellular lipolysis.

The main pro-lipolytic hormone during fasting is the catecholamine noradrenaline, produced and released from nerve endings that innervate the adipose tissue [118]. It acts by binding to transmembrane $\beta$-adrenergic receptors on the cell surface. Catecholamines stimulate three different $\beta$-adrenergic receptors, $\beta_{1}, \beta_{2}$ and $\beta_{3}$, but in human adipocytes primarily $\beta_{1}$ and $\beta_{2}$ affect lipolysis [119-121]. The adrenergic receptors are G-protein coupled receptors and upon ligand binding a conformational change of the cytoplasmic part of the receptor activates the $\alpha$ subunit of the G-protein. The $\alpha$-subunit exchanges its bound GDP for GTP and this leads to dissociation of the $\alpha$-subunit from the $\beta \gamma$-subunits. The $\beta$-adrenergic receptors in adipocytes are all coupled to dissociation of the Gas-subunit that stimulates adenylate cyclase to convert ATP to cAMP. cAMP then binds to and activates protein kinase A (PKA). PKA consists of two regulatory and two catalytic subunits, the two regulatory subunits bind two cAMP molecules each, after which the catalytic subunits can dissociate as two active monomers. Active PKA stimulates lipolysis by phosphorylating HSL and PLIN1. PKA phosphorylates HSL on three serine residues and PLIN1 has five PKA consensus phosphorylation sites [122-124].

Perilipins are proteins coating the lipid droplet, thus protecting TAGs from being hydrolysed, and in non-stimulated adipocytes PLIN1 is bound to comparative gene identification 58 (CGI58) [125]. PKA mediated phosphorylation of PLIN1 releases CGI-58 that can act as a coactivator of the adipose triglyceride lipase (ATGL) [126, 127]. ATGL hydrolyses TAG to diacylglycerol (DAG) releasing the first FA. Phosphorylated HSL translocates from the cytosol to the lipid droplet and breaks down DAG to monoacylglycerol (MAG), thus releasing a second FA. The last step that hydrolyses MAG to glycerol and one FA is completed by the monoglyceride lipase (MGL), which is not under hormonal control and the enzyme is most likely constitutively active (Fig. 7). 


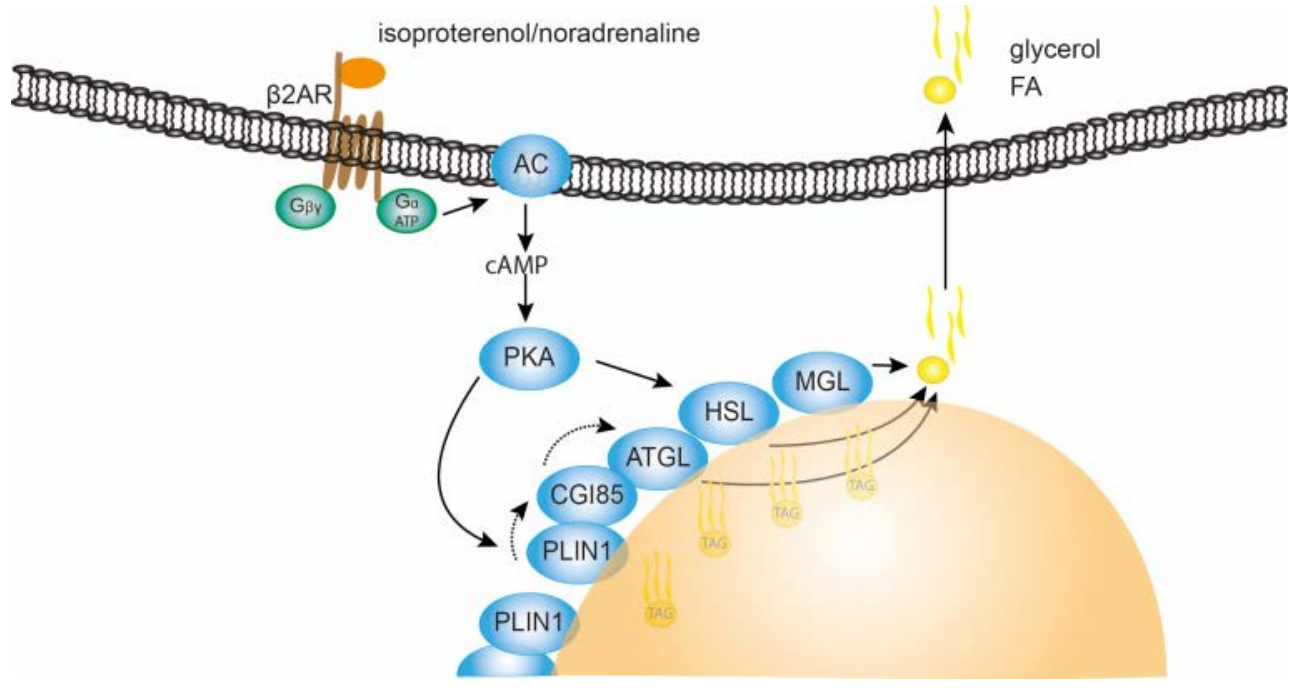

Figure 7. $\beta_{2}$-adrenergic stimulation activates adenylate cyclase to produce cAMP. cAMP the binds to and activates PKA that phosphorylates and activates PLINI and HSL. PLINI releases CGI-58 that can activate ATGL to hydrolyse TAG to DAG. HSL then hydrolyses DAG to MAG and MGL hydrolyses MAG to glycerol and FA. Thereafter one glycerol and three FA can be released.

\section{ATGL and HSL}

HSL was long believed to be responsible for TAG hydrolysis, but in 2004 three different research groups identified ATGL as the lipase initiating TAG breakdown [128-130]. ATGL is highly expressed in white adipose tissue. Activation of ATGL is dependent on interaction with the co-activator CGI-58 but the mechanism is still unclear [127]. Several different mutations in the ATGL gene have been reported in a subgroup of patients suffering from neutral lipid storage disease $[131,132]$. Most of the mutations lead to a truncated version of the protein but one patient have a loss of function mutation in the catalytic site [133, 134]. These patients suffer from systemic fat accumulation, muscle weakness and a quarter of the reported cases have T2D [135].

A knock-out mice model show that deficiency in ATGL causes increased lipid content in adipose tissue as well as ectopically, especially in the heart, causing premature death due to cardiac dysfunction [136]. The isoproterenol induced release of glycerol and FA was reduced in the knock-out animals, but the basal release was the same as for the wt. When ATGL was over expressed in 3T3-L1 adipocytes both the basal and isoproterenol-stimulated lipolysis was increased [137]. Knock down of ATGL in human differentiated pre-adipocytes or hMADS cells shows decreased basal lipolysis, but a reduced effect on the stimulated lipolysis in hMADS 
cells only $[138,139]$. There is no consensus regarding to what extent ATGL is affected in obesity. Reports of downregulated and unaffected protein levels have been described [140-142] and preliminary data from our lab show that ATGL protein levels are slightly reduced or not affected in human adipocytes from obese T2D subjects compared to controls.

HSL is an important protein for maintaining the lipid and glucose homeostasis. HSL has the ability to hydrolyze all three steps in breaking down TAG in vitro. But its main role in vivo is to hydrolyze DAG [139]. Humans with mutations in HSL and HSL-knock-out mice accumulate DAG in the adipose tissue $[143,144]$. When an Amish population with extremely high fasting serum triglyceride levels was sequenced for genes involved in the lipolytic pathway, a null mutation was found in the gene encoding HSL. This mutation caused T2D in homozygotes and an increased risk for T2D in heterozygotes. Carriers of the loss of function mutant had small adipocytes, impaired lipolysis and ectopic storage of fat in the liver [144].

When HSL was knocked down with siRNA in human differentiated pre-adipocytes or hMADS cells, the isoproterenol or forskolin stimulated lipolysis was reduced but only the differentiated pre-adipocytes exhibited reduced basal lipolysis [138, 139]. The protein levels of HSL have been reported to be decreased in obese subjects compared to lean $[145,146]$. Our preliminary data show a tendency to reduced levels in obese T2D compared to lean non diabetics but the difference is not statistically significant. This discrepancy could be due to smaller difference in body mass index (BMI) between the groups and number of subjects in the study. However, the physiological significance of reduced levels of HSL in T2D is questionable, since we and others see no difference in glycerol release from adipocytes between nondiabetic and diabetic individuals (paper III) [147].

In unstimulated cells HSL is mainly found in the cytosol but relocates after adrenergic stimulation and phosphorylation to the lipid droplet. At first two phosphorylation sites of HSL were described, called the regulatory and the basal site [148], they were later on identified as Ser552 and Ser554. They are mutually exclusive and under basal conditions Ser554 is phosphorylated by AMPK hindering PKA from phosphorylating the Ser552 site. Later three additional phosphorylation sites, that all increase the activity of HSL, were reported, where Ser649 and Ser650 are phosphorylated by PKA and Ser589 by ERK $[123,149,150]$.

\section{Negative regulation of lipolysis via cAMP}

In response to cAMP, PKA also activates a negative feedback in the control of lipolysis by phosphorylation and activation of PDE3B that hydrolyses cAMP to AMP and thereby decreases lipolysis [151-153]. In paper III we also unravel an additional negative feedback induced by the 
adrenergic increase of cAMP. We found that isoproterenol increases the phosphorylation of $\mathrm{PKB}$ at Ser473. Active PKB is well known to phosphorylate and activate PDE3B to decrease cAMP levels and hence also lipolysis $[154,155]$. The phosphorylation of PKB in response to isoproterenol was inhibited by the PI3K-inhibitor wortmannin, by the mTOR-inhibitor torin, or by the PKB-inhibitor Akti1/2, but not by the mTORC1-inhibitor rapamycin. Inhibition with either wortmannin, torin or Akti1/2 increased the cellular levels of cAMP, phosphorylation of HSL and lipolysis. This adrenergic-induced phosphorylation of PKB-Ser473 was partially reduced by inhibition of PKA or exchange protein directly activated by cAMP-1 (Epac1), while the combined inhibition of PKA and Epac1 decreased the phosphorylation of PKB-Ser473 back to basal levels.

These results demonstrate a pathway where beta-adrenergic stimulation increases cAMP levels, which in turn via activation of PKA and Epac1 induce phosphorylation PKB-Ser473 in a PI3K and mTORC2-dependent manner (Fig. 8). These data are in line with findings in brown adipocytes from mice, where noradrenaline induced PKB-Ser473 phosphorylation that was inhibited by either torin, wortmannin or an Epac1 inhibitor (however not with a PKA inhibitor) [156]. Likewise in rat adipocytes $\beta 3$-agonist induced PKB-Ser473 phosphorylation that could be inhibited by wortmannin or inhibition of PKA [157]. In other cell types it has been shown that cAMP activation of Epac activates or potentiates insulin activation of PKB, in a PI3Kdependent manner, but PKA, in contrast, inhibited PKB [158, 159]. In 3T3-L1 cells, in a different context, PKA and Epac have been shown to work in a synergistic way to stimulate adipogenesis [160].

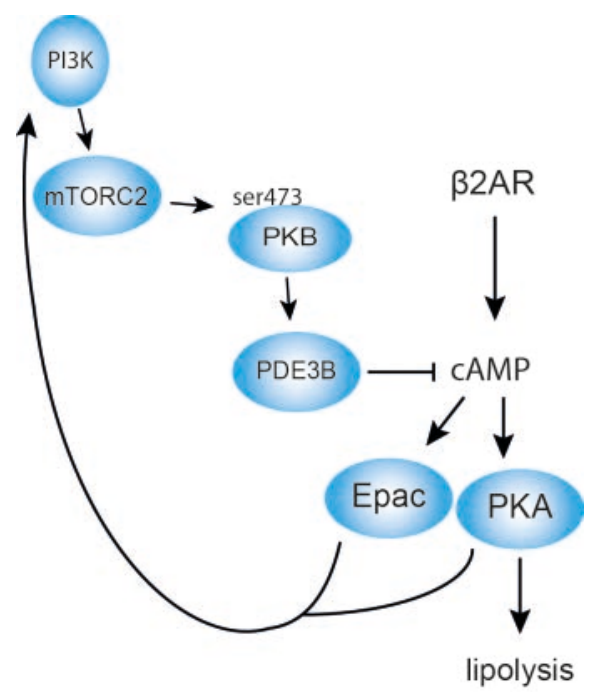

Figure 8. $\beta$-adrenergic-stimulation creates a negative feedback where increased cAMP levels and activation of PKA and Epac activates PKB. This occurs in a PI3K and mTORC2 dependent way. 
The cAMP-dependent signalling routes seem to be cell type and species specific and probably agonist concentration dependent. Our findings in primary human adipocytes demonstrate a negative feedback for control of lipolysis, where beta-adrenergic stimulation via cAMP signals - both through Epac1 and PKA - to activation of PI3K and mTORC2 to increase the phosphorylation of PKB at Ser473 and thus activate PDE3B to decrease cAMP levels and lipolysis. Hence, inhibition of this feedback doubled the lipolytic response to $\beta$-adrenergic stimulation (paper III).

\section{$\alpha_{2}$-Adrenergic inhibition of lipolysis}

Another control mechanism of lipolysis is that catecholamines also bind to $\alpha_{2}$-adrenergic receptors on adipocytes. These receptors are coupled to the Gai-subunit that in contrast to Gas inhibits adenylate cyclase and thereby decreases the cellular levels of cAMP. In human adipocytes the catecholamines have a higher affinity for $\alpha_{2}$-receptors than for the $\beta_{1}$ and $\beta_{2}$ receptors [161], perhaps to control and inhibit basal lipolysis [162]. The ratio of $\alpha_{2} / \beta$-receptors has been reported to differ between different adipose depots and to increase with adipocyte hypertrophy and obesity [163-166]. The $\beta$ - but not $\alpha_{2}$-receptors undergo desensitization after long term stimulation or stimulation with high concentrations of agonist [161]. The $\beta$ adrenergic receptor is phosphorylated either by G-protein coupled receptor kinase creating a binding site for $\beta$-arrestin that promotes internalization of the receptor via clathrin-coated vesicle endocytosis or via PKA and caveolae [167, 168]. Hence, catecholamines stimulate lipolysis but also ascertain that it is well controlled, both at receptor level and intracellularly via PKA-mediated negative feedback signals. To ensure that we only activate the $\beta$-adrenergic receptors, and thus simplify interpretation of the results, we have in our experiments used the noradrenaline analogue isoproterenol, which is a selective agonist for $\beta$-adrenergic receptors and does not stimulate the $\alpha_{2}$-adrenergic receptors.

\section{Insulin control of lipolysis}

Lipolysis is suppressed by insulin and the general view on how insulin transmits this signal is via PI3K activation of PKB that in turn phosphorylates and activates PDE3B to degrade cAMP into AMP $[155,169,170]$. PKA activation is then reduced and thereby also the phosphorylation of HSL and PLIN1, which leads to reduced lipolysis - the anti-lipolytic action of insulin (Fig. 9). This view has, however, recently been challenged. Choi et. al. showed in 3T3-L1 adipocytes that at submaximal levels $(<12.5 \mathrm{nM})$ of isoproterenol stimulation, insulin acted in a PI3K- 
dependent but a PKB-independent manner to inhibit lipolysis [171]. Later the same research group confirmed in brown adipocytes from PDE3B knock out animals the importance of PDE3B for insulin-mediated anti-lipolysis; but by reintroducing PDE3B with the PKB specific phospho-sites ablated they also reported that phosphorylation of PDE3B by PKB was not required for insulin to suppress lipolysis [172]. They suggested that insulin inhibits PKA locally on the lipid droplet, possibly by stimulating the formation of a protein complex comprising PDE3B and other negative regulators of PKA signalling, referring to the formation of macromolecule complexes in adipocytes in response to insulin and $\beta_{3}$-adrenergic receptor agonist stimulation [173]. The insulin-stimulated complex contained phosphorylated PDE3B, IRS1, PI3K p85, PKB, HSP-90, 14-3-3, caveolin-1 and PP2A and adrenergic stimulation formed a complex with phosphorylated PDE3B, PKA-RII, 14-3-3, $\beta_{3}-\mathrm{AR}$, caveolin-1 and PP2A [173].

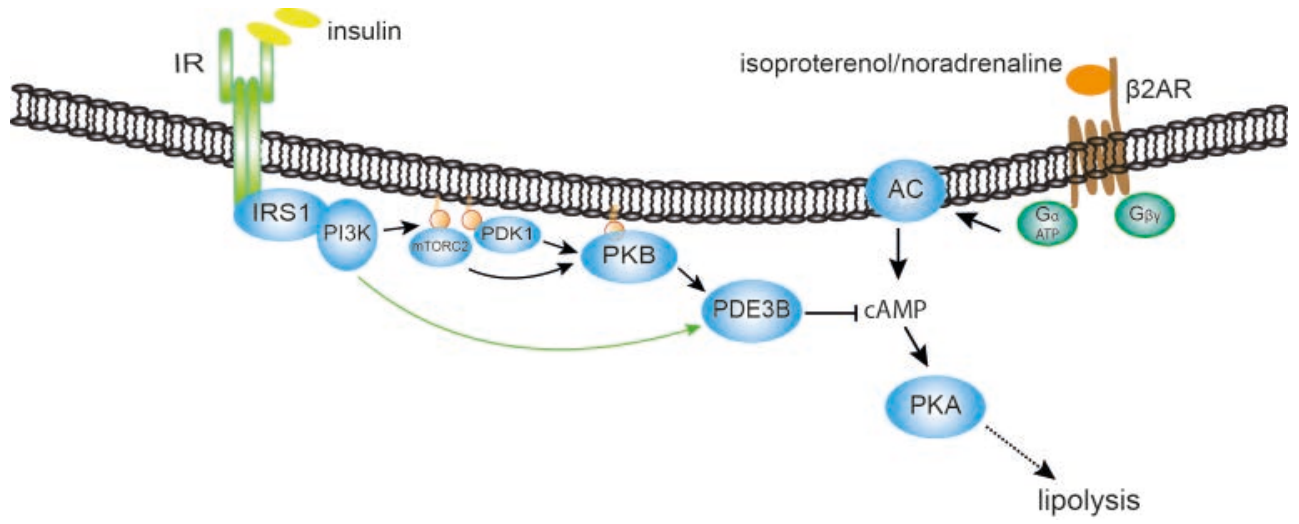

Figure 9. Insulin stimulated anti-lipolysis. Black arrows indicate the general view where PI3K generated PIP3 activates PKB to phosphorylate and activate PDE3B to degradate cAMP. Green arrow indicate the PKB-independent but PI3K-dependent activation of PDE3B and cAMP hydrolysis.

In paper III we show that the anti-lipolytic effect of insulin has to involve activation of PDE3B. We also show that the insulin-stimulated antilipolysis is mediated by a PI3K-dependent, but a PKB-independent, pathway in human adipocytes (Fig. 9). When we stimulated human adipocytes with $10 \mathrm{nM}$ isoproterenol insulin reduced cAMP levels and inhibited lipolysis in a dose-dependent manner even though mTOR or PKB were inhibited. However, when PI3K was inhibited with wortmannin the anti-lipolytic effect of insulin was blocked. That the inhibition of PI3K also affected the cAMP levels indicates that the activity of PDE3B was affected in the human adipocytes. To confirm the involvement of PDE3B we used a PDE3-specific inhibitor, cilostamide, and found that in the presence of this PDE3-inhibitor insulin could not suppress cAMP production or lipolysis. This means that PDE3B activation is required for the insulin- 
mediated suppression of lipolysis, and that insulin activates PDE3B mainly in a PKBindependent way. However we found a PKB-dependent activation of cAMP hydrolysis by isoproterenol, and we suggest that this masks a PKB-dependent activation of PDE3B by insulin, perhaps by saturation of specific PKB phosphorylation sites on PDE3B. It is possible that the isoproterenol-induced activation of $\mathrm{PKB}$ and thereby $\mathrm{PDE} 3 \mathrm{~B}$ is transient and that the insulininduced activation of $\mathrm{PKB}$ and $\mathrm{PDE} 3 \mathrm{~B}$ is more pronounced at later time points than we have measured in paper III. In brown adipocytes the phosphorylation of PKB at Ser473 reached a max after 5 min of stimulation with isoproterenol and thereafter declined to basal levels after $60 \mathrm{~min}$ of isoproterenol stimulation [156]. The combination of different concentrations of insulin and isoproterenol could also be of importance regarding the activation of the different pathways for control of PDE3B. Choi et al found that insulin could suppress lipolysis in 3T3L1 adipocytes also in a PKB-dependent manner if the adipocytes where stimulated with high $(>12.5 \mathrm{nM})$ concentration of isoproterenol [171].

To explain how insulin inhibits isoproterenol-stimulated lipolysis it is apparent that more than one pathway is required. While the PKB-dependent pathway is the more studied, there remains much to be unravelled concerning the PKB-independent pathway(s). As mentioned above PI3Ks can act as both lipid and protein kinases and as scaffolding proteins, providing possibilities for other mechanisms than the canonical PI3K pathway of PIP3 generation. Moreover, specific protein-kinase activity of PI3K was in human adipocytes stimulated by insulin and co-immunoprecipitated with IR and PDE3B, while the stimulated lipid-kinase activity of PI3K co-immunoprecipitated with IRS1 [174]. The phosphorylation and activity of PDE3B also increased in the IR-precipitate upon insulin stimulation. It could not be excluded that there was an additional protein kinase in the IR-precipitate that phosphorylates PDE3B, but PKB was not found in the IR-precipitate [174]. PDE3B phosphorylation and activity can also be controlled by regulated dephosphorylation. The complexes formed upon insulin or adrenergic stimulation are intriguing. PP2A can dephosphorylate PDE3B in vitro and also decreased the phosphorylation in vivo in rat adipocytes [175]. In mouse embryonic fibroblasts PI3K $\gamma$ has been shown to bind PP2A and thereby promote sustained ERK activation after insulin stimulation [176]. It is tempting to speculate about a similar control of PDE3B. 


\section{A biphasic lipolytic response to insulin}

To our surprise we found that the effect of insulin on isoproterenol-stimulated lipolysis was biphasic, such that at higher concentrations than $0.1 \mathrm{nM}$ insulin increasingly lost its antilipolytic effect (Fig. 10).

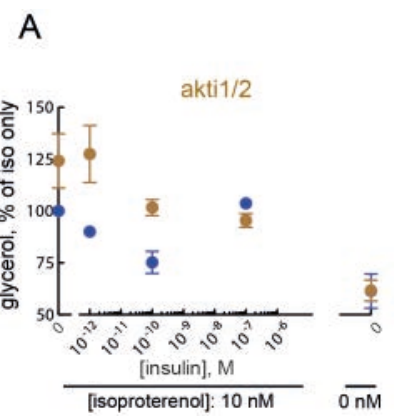

B

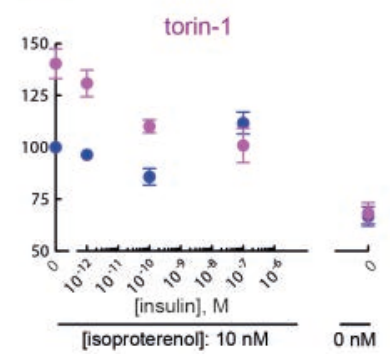

C

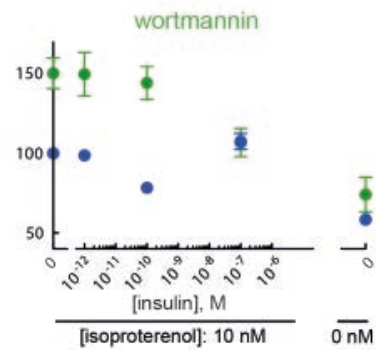

Figure 10. Insulin at increasing concentrations induces a biphasic lipolytic response when added to isoproterenol-stimulated adipocytes. Blue circles denote control experiments. In the presence of a (A) mTOR- or a (B) PKB-inhibitor isoproterenolstimulated lipolysis is increased and insulin can in a dose-dependent manner inhibit lipolysis. (C) In the presence of a PI3Kinhibitor isoproterenol-stimulated lipolysis is increased but insulin can no longer inhibit lipolysis. Using either of the inhibitors (A-C) the biphasic response to insulin was lost.

We found that this biphasic effect had been described before but with no attempt to try to explain the phenomenon [177-180]. Based on our experimental results (Fig. 10) we hypothesized that the loss of insulins anti-lipolytic effect is due to a negative feedback from PKB to the PKB-independent anti-lipolytic pathway described above. We believe that a substrate downstream of PKB with a right shifted dose response curve (compared to the PKBdependent PDE3B-activation) turns off the PKB-independent activation of PDE3B and thereby inhibits the degradation of cAMP (Fig. 11).

This feedback could for example be activation of a phosphatase, a kinase phosphorylating PDE3B at a deactivating site or disruption of important protein complexes. Since we know that $\beta$-adrenergic stimulation not only stimulates lipolysis but also controls lipolysis with negative feedback signals, it is not surprising that insulin acts in a similar way to control antilipolysis. As the feedback has effect at concentrations of insulin exceeding $0.1 \mathrm{nM}$ and as insulin levels in the blood can reach a concentration of $2 \mathrm{nM}$ one hour after glucose administration, the feedback signal could well be of physiological and pathophysiological relevance. The loss of antilipolysis at high concentrations of insulin may for example protect from a complete inhibition of lipolysis during hyperinsulinemia. In paper III we further discuss the functional role of the bi-phasic response to insulin in the context of multiple feedback signals that we have identified in the insulin/ $\beta$-adrenergic control of lipolysis. 


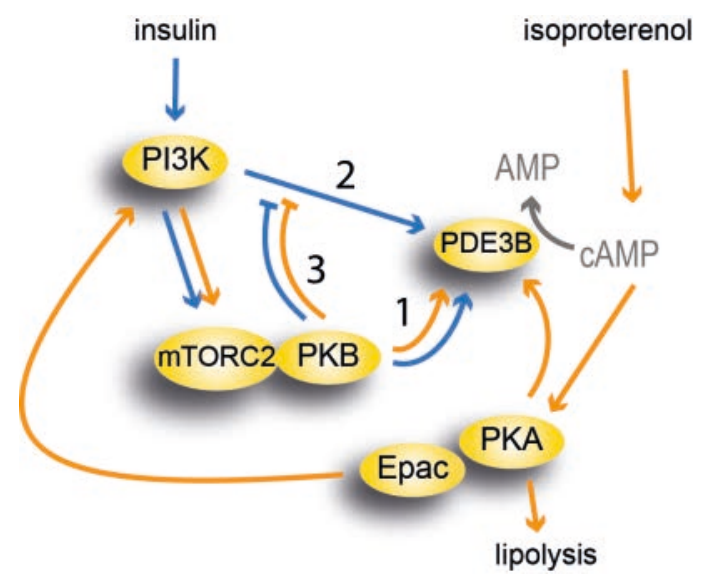

Figure 11. Complex regulation of CAMP and lipolysis in response to insulin and $\beta$-adrenergic stimulation. 1, indicates the $P K B$-dependent isoproterenol and insulin stimulated activation of PDE3B. 2, indicates the PKB-independent activation of $P D E 3 B$. 3, indicates the negative feedback from $P K B$ to the PKB-independent activation of PDE3B that is activated at high insulin concentration.

\section{Lipolysis in T2D}

In the literature there is no consensus on how the regulation of lipolysis is affected in obesity and T2D. There are reports of decreased or unaffected lipolysis in response to adrenergic stimulation in diabetes $[147,181]$. Likewise, insulin-mediated antilipolysis has been variously reported as, normal, increased or decreased in diabetes [147, 181, 182]. In paper III we measure the release of glycerol and FA from adipocytes obtained from obese patients diagnosed with T2D and with a BMI $>28$ and from control patients with $\mathrm{BMI}<28$. This ascertains that we only include T2D related to obesity although some of the control subjects may be over-weight. We show that in mature human primary adipocytes there is no difference in lipolysis between cells from T2D and control subjects, neither the isoproterenol stimulated lipolysis nor the ability of insulin to reduce lipolysis was affected in the diabetic state (paper III). Neither was the sensitivity to the anti-lipolytic effect of insulin affected in the diabetic state. However, the release of FA is increased in the diabetic state, during stimulation with isoproterenol and when the cells are stimulated with different concentrations of insulin in the presence of isoproterenol.

Thus we found that in isolated adipocytes there is no difference in glycerol released from T2D compared with control cells, but the FA release was increased by $50 \%$. When calculating the difference of glycerol and FA released from the same cells we find that the extent of reesterification is reduced in T2D, which thus can explain the augmented release of FA from T2D adipocytes. We found no short term effect of isoproterenol or of isoproterenol with different 
concentrations of insulin on the re-esterification, which suggests that the regulation is mainly at a transcriptional level (paper III). In agreement with our results, a recent paper reported that during an oral glucose tolerance test there was no difference in glycerol but elevated FA release when comparing T2D and control subjects [147]. Also in this report, the release of glycerol from isolated adipocytes obtained from T2D patients did not differ from controls. There were no difference in transcripts of genes associated with lipolysis like ATGL or HSL, but reduced levels of lipogenic genes like acylglycerol-3-P acyltransferase (AGPAT), diacylglycerol acyltransferase (DGAT) and fatty acid synthase in fat cells from T2D patients [147]. Also microdialysis measurements of basal and isoproterenol induced glycerol release from abdominal subcutaneous adipose tissue has shown no difference between T2D and control subjects [183]. Other studies in human adipose tissue have found that basal lipolysis was increased in obesity, but no difference in the insulin sensitivity for antilipolysis [177, 184]. In contrast, reduced insulin sensitivity for the anti-lipolytic effect has been found in obese women [185]. Reduced catecholamine-stimulated lipolysis has been explained by reduced expression of $\beta 2 \mathrm{AR}$, increased expression of $\alpha 2$-receptors or decreased expression of HSL [186]. If increased expression of $\alpha 2 \mathrm{AR}$ is the reason for reduced catecholamine stimulated lipolysis that could explain why we did not see this reduction, since we used a $\beta$ AR specific agonist.

The lipolytically released FA can be oxidized in the adipocyte, transported out of the cell or recycled and incorporated back into TAG [187]. The percentage of FA that are oxidized in the adipocyte is low and the fraction of FAs that are re-esterified is individual, and under basal conditions the percentage of FA re-esterified ranged from $0-100 \%$ [188]. The individual reesterification is something we also observe in our experiments (paper III). To re-esterify FA into TAG glycerol-3-phosphate (G3P) is required. The ability of the adipocytes to utilise glycerol as a precursor for G3P is very limited as adipocytes has a low expression of the enzyme GyK that converts glycerol to G3P. However, treatment with anti-T2D drugs like rosiglitazone can induce the expression of GyK and increase the re-esterification and the incorporation of glycerol into TAG $[189,190]$. More important sources for G3P production are conversion of glucose via glycolysis or from non-carbohydrates like pyruvate, lactate or amino acids through glyceroneogenesis. The relative contribution of these two pathways is not completely understood and most probably they occur in parallel and that fed/fasted state and diet effect their contribution [191, 192].

The potentially harmful effect that non-esterified FA has on adipose tissue and non-adipose tissue makes it important to control the accumulation of FA in the cells. The re-esterification seems to be a central part of this control system. Recently published data show that reesterification during lipolysis in adipocytes protects against ER-stress and that DGAT1 is 
responsible for the protection of ER lipotoxic stress [193]. DGAT is one of the three acyltransferases involved in TAG synthesis. Glycerol-3-P acyltransferase (GPAT) is the first enzyme to add a FA to G3P then AGPAT adds a second FA and finally DGAT adds the third FA to complete the synthesis. In preliminary experiments we see reduced mRNA levels of GPAT3 and AGPAT4 in adipocytes from T2D patients compared to non-diabetics. 


\section{Concluding remarks and future perspective}

The adipose tissue has to be at the centre of attention when trying to elucidate the mechanisms behind insulin resistance and T2D. The findings described in this thesis have expanded our knowledge regarding insulin signalling and its dysregulation connected to T2D in human adipocytes. These findings in return also evoked new questions in need of answers.

Paper I: We found the phosphorylation of IRS1 at Ser307 not to be catalysed by either S6K1 or mTOR in human adipocytes. Thus the endogenous kinase remains to be established. That the phosphorylation of IRS1 at Ser307 is attenuated in T2D and that the phosphorylation of serineand threonine-residues of IRS1 alters its activity makes it highly interesting to further explore the pattern of phosphorylation of IRS1 and the kinases involved.

Paper II: We found the protein IQGAP1 to be expressed in human adipocytes and that the expression was reduced in T2D. We also found IQGAP1 to interact with caveolae and that this interaction was increased upon insulin stimulation. These findings together with the recently published data regarding IQGAP1s interaction with many of the proteins involved in the insulin signalling network indicate an important role of this scaffolding protein in the transduction of the insulin signal. Much is left to discover regarding cell specific interactions and regulation involving IQGAP1.

Paper III: That lipolysis is un-affected in the diabetic state, but the re-esterification of FA is reduced in T2D, highlights the importance of future studies concerning the molecular details of how insulin is involved in mechanisms that control the re-esterification process. We demonstrate that the insulin-stimulated anti-lipolytic effect is mediated by PI3K but in a PKBindependent activation of PDE3B, however, the identity of the PI3K and the mechanisms remain to be identified. We found that high concentrations of insulin decreased the anti-lipolytic effect of insulin and we suggest that this is due to a negative feedback to the PI3K activation of PDE3B. With the use of mathematical modelling in combination with experimental data this hypothesis will be interesting to test. Together with the finding of an additional negative feedback in the $\beta$-adrenergic control of lipolysis we have demonstrated that the regulation of lipolysis is much more complex than has been previously described. 


\section{Acknowledgment}

During my (many) years as a $\mathrm{PhD}$ student I've met a lot of inspiring people. Even though the Strålfors group became smaller and smaller, my interest in science has only grown bigger and bigger! This thesis could not have been done without the support and encouragement from a lot of people and for this I am very grateful. I especially would like to thank:

My supervisor Peter Strålfors, your scientific knowledge is truly inspiring. Your door is always open and you always take the time to answer my numerous questions. When you first asked me to support the lipolysis project I was not too happy about it but I have definitely changed my mind! This last project has really made me develop as a researcher, with you as my guide, and I have enjoyed our many scientific (and non-scientific) discussions. Your enthusiasm is contagious!

Maria Turkina my co-supervisor and mass-spec. guru. The spark that lit up in your eyes when I say I need to do some mass-spec is priceless. The next day you have read ten papers on the matter and know what additional experiment I need and don't need to do. I've enjoyed our many chats and tried to absorb as much as I can of your knowledge regardless if it's about proteomics, design or antiques whether it's in the office or family get-togethers with the Jufvas's.

My co-authors, former roomies and still good friends, Åsa Jufvas, Siri Aili Fagerholm and Meenu Rajan. You all left me, to do research in Gothenburg or hunt criminals at NFC and I miss you in the lab every day! I also miss you in the office there was sooo much we could talk about. Åsa, your sense of order is something I strive to copy both in the lab and writing lab book. Even though your interest in discussing lab protocols with me has decreased we never run out of topics to talk about. What would we have done without you during the weekends? We can always count on you and Johan when we need to "rasta våra barn" hanging out in Alguvi or help to pimp our cabin. Siri you are so calm and kind but never afraid to speak your mind. Thank you for being my insulin signaling encyclopedia in the beginning. Thank you for always answering my questions when I turned around and disturbed you while writing your thesis, whether the question was about IRS1 or life in general. Meenu you are so hard working and inspiring, I know you will make it in science. I miss our chats and your tips about Indian cooking and how to tie my sari! I promise you I will continue to watch Bollywood movies.

Former members of the group Elin Nyman and Cecilia Brännmark. Elin, it's good to have you back in Sweden! Thank you for all the help with statistics and discussions about my results and politics! I can always count on you bringing me positive energy and honey. Ia we have had 
more collaborations since you left the group and I hope it will continue. Thank you for always making sure we get some local beer after the conferences in Gothenburg!

I would like to thank all former and present co-worker at floor 12:

My master thesis supervisors Sven Hammarström, Mats Söderström and Tobias Strid, thank you for guiding me during my first year in science. Tobias, since you left I miss to have someone to share quotes from Christer Ulfbåge från "stödbollen" with! Mats, my steady "fika partner" and unofficial co-supervisor, thank you for all your help during the years. I really enjoy our conversations and the fact that you are the only one on the floor I can talk about sports with!

Anita Öst's group, Anita, Unn Kugelberg, Lovisa Örkelby, Rashmi Ramesh, Marie Roth and Magnus Baumgardt you make lunch time one of the highlights of the day. Even though Magnus knowledge about EHEC and norovirus sometimes ruins a former meal and making me and Unn count incubation days.

Annika Thorsell's group, Annika, Lovisa Holm, Riccardo Barchiesi, Daniel Nätt, Estelle Barbier and Esi Domi thank you for interesting discussions in the coffee room and fun Christmas parties.

Marie Oskarsson, Sebastian Schultz and Sofia Nyström, the discussions in the coffee room became less energetic after you left, but Sebastian I hope I convinced you about how outstanding Swedish music export really is before you moved.

Also a big thank you to:

Björn Ingelsson, always there when I need some good gossip! I hope you stay so we can continue to have lunch, discuss lab-protocols and exchange chemicals for another couple of years.

Thank you Stefan Klintström, Charlotte Immerstrand and all the Forum Scientium members for the nice conferences and meetings where I got the great opportunity to present my work and get input from researchers in other fields and to learn about their research. I would also like to thank Preben Kjølhede and the staff at the department of gynecology for providing us with adipose tissue for our research.

I would also like to thank friends and family who supported me outside of work during this time.

Tack till Eduardo och Ellen för trevliga utflykter och middagar även om Eddie varje gång är tvungen att fråga "när är du klar egentligen?" Julia och Martin, tack för allt mysigt häng och 
gourmetmiddagar i mysbyxor. Marie och Amy, även om vi inte tar oss tid att ses så ofta är det alltid som på den gamla goda tiden när vi gör det.

Anna och Daniel, tack för ett fantastiskt år i Indien och alla gillen på Stenhagen, ni vet verkligen hur man ställer till med fest!

Familjerna Jönsson, Arne och Pia de bästa svärföräldrarna man kan tänka sig! Er kan man prata med om allt mellan himmel och jord. Tack till Hampus och Jessica, vad skulle jag göra utan dig Hampus när Johan är bortrest? Du kan det mesta om det mesta när det behöver fixas och trixas.

Min underbara familj, Mamma, tack för att du alltid finns där och stöttar även om du titt som tätt får fråga "vad är det egentligen du håller på med på jobbet?” Tack till Anna och Nick, Anna min barndomsidol, saknar dig så och tycker det börjar bli dags för er att flytta hem! Martina och Jonas, tack för att ni huserar alla familjeträffar och myshäng med våra barn. Och tack för att ni tålmodigt svarar på alla sjukdomsrelaterade frågor från en hypokondrisk lillasyster!

Till sist mina tre käraste, Johan min underbara, fantastiska Johan, jag skulle inte kunna tänka mig mitt liv utan dig. Ingen förstår min humor som du och står ut med mitt humör $\odot$. Och tänk att vi har skapat de bästa barnen i världen, Edvard och Melker. Så olika men perfekta båda två som kan dränera men på samma gång ge så mycket energi. Tack för all kärlek! 


\section{References}

1. Zwick, R.K., et al., Anatomical, Physiological, and Functional Diversity of Adipose Tissue. Cell Metab, 2018. 27(1): p. 68-83.

2. Ortegren, U., et al., A new role for caveolae as metabolic platforms. Trends Endocrinol Metab, 2007. 18(9): p. 344-9.

3. McLaughlin, T., et al., Subcutaneous adipose cell size and distribution: Relationship to insulin resistance and body fat. Obesity, 2014. 22(3): p. 673-680.

4. Kim, J.I., et al., Lipid-Overloaded Enlarged Adipocytes Provoke Insulin Resistance Independent of Inflammation. Molecular and Cellular Biology, 2015. 35(10): p. 1686-1699.

5. Julius, U., et al., Basal and stimulated hyperinsulinemia in obesity: relationship to adipose-cell size. Endokrinologie, 1979. 73(2): p. 214-220.

6. Odegaard, J.I. and A. Chawla, Pleiotropic Actions of Insulin Resistance and Inflammation in Metabolic Homeostasis. Science, 2013. 339(6116): p. 172-177.

7. Cinti, S., et al., Adipocyte death defines macrophage localization and function in adipose tissue of obese mice and humans. Journal of lipid research, 2005. 46(11): p. 2347-2355.

8. Shulman , G.I., Ectopic Fat in Insulin Resistance, Dyslipidemia, and Cardiometabolic Disease. New England Journal of Medicine, 2014. 371(12): p. 1131-1141.

9. Janikiewicz, J., et al., Islet B-cell failure in type 2 diabetes - Within the network of toxic lipids. Biochemical and Biophysical Research Communications, 2015. 460(3): p. 491-496.

10. Jonas, J.C., et al., Glucose regulation of islet stress responses and beta-cell failure in type 2 diabetes. Diabetes Obes Metab, 2009. 11 Suppl 4: p. 65-81.

11. Cefalu, W.T., Animal Models of Type 2 Diabetes: Clinical Presentation and Pathophysiological Relevance to the Human Condition. ILAR Journal, 2006. 47(3): p. 186-198.

12. King, A.J.F., The use of animal models in diabetes research. British Journal of Pharmacology, 2012. 166(3): p. 877-894.

13. Chusyd, D.E., et al., Relationships between Rodent White Adipose Fat Pads and Human White Adipose Fat Depots. Front Nutr, 2016. 3: p. 10.

14. Of men, not mice. Nature Medicine, 2013. 19: p. 379.

15. Gjedsted, J., et al., Effects of a 3-day fast on regional lipid and glucose metabolism in human skeletal muscle and adipose tissue. Acta Physiologica, 2007. 191(3): p. 205-216.

16. Zauner, C., et al., Resting energy expenditure in short-term starvation is increased as a result of an increase in serum norepinephrine. Am J Clin Nutr, 2000. 71(6): p. 1511-5.

17. Taniguchi, C.M., B. Emanuelli, and C.R. Kahn, Critical nodes in signalling pathways: insights into insulin action. Nat Rev Mol Cell Biol, 2006. 7(2): p. 85-96.

18. Kadowaki, T., et al., SnapShot: Insulin Signaling Pathways. Cell. 148(3): p. 624-624.e1.

19. Manning, B.D. and A. Toker, AKT/PKB Signaling: Navigating the Network. Cell, 2017. 169(3): p. 381-405.

20. Liu, P., et al., PtdIns(3,4,5)P3-Dependent Activation of the mTORC2 Kinase Complex. Cancer Discov, 2015. 5(11): p. 1194-209.

21. Rajan, M.R., et al., Systems-wide Experimental and Modeling Analysis of Insulin Signaling through Forkhead Box Protein 01 (FOXO1) in Human Adipocytes, Normally and in Type 2 Diabetes. J Biol Chem, 2016. 291(30): p. 15806-19.

22. Guertin, D.A., et al., Ablation in mice of the mTORC components raptor, rictor, or mLST8 reveals that mTORC2 is required for signaling to Akt-FOXO and PKCalpha, but not S6K1. Dev Cell, 2006. 11(6): p. 859-71.

23. Jacinto, E., et al., SIN1/MIP1 maintains rictor-mTOR complex integrity and regulates Akt phosphorylation and substrate specificity. Cell, 2006. 127(1): p. 125-37. 
24. Manning, B.D., et al., Identification of the tuberous sclerosis complex-2 tumor suppressor gene product tuberin as a target of the phosphoinositide 3-Kinase/Akt pathway. Molecular Cell, 2002. 10(1): p. 151-162.

25. Cortes, V.A. and M. Fernandez-Galilea, Lipodystrophies: adipose tissue disorders with severe metabolic implications. J Physiol Biochem, 2015. 71(3): p. 471-8.

26. Abel, E.D., et al., Adipose-selective targeting of the GLUT4 gene impairs insulin action in muscle and liver. Nature, 2001. 409(6821): p. 729-33.

27. Fam, B.C., et al., Normal muscle glucose uptake in mice deficient in muscle GLUT4. J Endocrinol, 2012. 214(3): p. 313-27.

28. Morley, T.S., J.Y. Xia, and P.E. Scherer, Selective enhancement of insulin sensitivity in the mature adipocyte is sufficient for systemic metabolic improvements. Nat Commun, 2015. 6: p. 7906.

29. Iozzo, P., Viewpoints on the way to the consensus session: where does insulin resistance start? The adipose tissue. Diabetes Care, 2009. 32 Suppl 2: p. S168-73.

30. Cook, J.R., et al., Pathogenesis of Selective Insulin Resistance in Isolated Hepatocytes. Journal of Biological Chemistry, 2015. 290(22): p. 13972-13980.

31. Shimomura, I., et al., Decreased IRS-2 and Increased SREBP-1c Lead to Mixed Insulin Resistance and Sensitivity in Livers of Lipodystrophic and <em>ob/ob</em> Mice. Molecular Cell. 6(1): p. 77-86.

32. Tan, S.X., et al., Selective insulin resistance in adipocytes. J Biol Chem, 2015. 290(18): p. 1133748.

33. Nyman, E., et al., A Single Mechanism Can Explain Network-wide Insulin Resistance in Adipocytes from Obese Patients with Type 2 Diabetes. Journal of Biological Chemistry, 2014. 289(48): p. 33215-33230.

34. Danielsson, A., et al., Attenuation of Insulin-stimulated Insulin Receptor Substrate-1 Serine 307 Phosphorylation in Insulin Resistance of Type 2 Diabetes. Journal of Biological Chemistry, 2005. 280(41): p. 34389-34392.

35. Lavin, D.P., M.F. White, and D.P. Brazil, IRS proteins and diabetic complications. Diabetologia, 2016. 59(11): p. 2280-2291.

36. Kido, Y., et al., Tissue-specific insulin resistance in mice with mutations in the insulin receptor, IRS-1, and IRS-2. The Journal of Clinical Investigation, 2000. 105(2): p. 199-205.

37. Thirone, A.C.P., C. Huang, and A. Klip, Tissue-specific roles of IRS proteins in insulin signaling and glucose transport. Trends in Endocrinology \& Metabolism, 2006. 17(2): p. 72-78.

38. Weigert, C., et al., Interplay and Effects of Temporal Changes in the Phosphorylation State of Serine-302, -307, and -318 of Insulin Receptor Substrate-1 on Insulin Action in Skeletal Muscle Cells. Molecular Endocrinology, 2008. 22(12): p. 2729-2740.

39. Giraud, J., et al., Nutrient-dependent and insulin-stimulated phosphorylation of insulin receptor substrate-1 on serine 302 correlates with increased insulin signaling. J Biol Chem, 2004. 279(5): p. 3447-54.

40. Werner, E.D., et al., Insulin Resistance Due to Phosphorylation of Insulin Receptor Substrate-1 at Serine 302. Journal of Biological Chemistry, 2004. 279(34): p. 35298-35305.

41. Copps, K.D., et al., Serine 302 Phosphorylation of Mouse Insulin Receptor Substrate 1 (IRS1) Is Dispensable for Normal Insulin Signaling and Feedback Regulation by Hepatic S6 Kinase. J Biol Chem, 2016. 291(16): p. 8602-17.

42. Greene, M.W., et al., Modulation of human insulin receptor substrate-1 tyrosine phosphorylation by protein kinase Cdelta. Biochem J, 2004. 378(Pt 1): p. 105-16.

43. Paz, K., et al., Phosphorylation of Insulin Receptor Substrate-1 (IRS-1) by Protein Kinase B Positively Regulates IRS-1 Function. Journal of Biological Chemistry, 1999. 274(40): p. 2881628822.

44. Shah, O.J. and T. Hunter, Turnover of the Active Fraction of IRS1 Involves Raptor-mTOR- and S6K1-Dependent Serine Phosphorylation in Cell Culture Models of Tuberous Sclerosis. Molecular and Cellular Biology, 2006. 26(17): p. 6425-6434. 
45. Harrington, L.S., et al., The TSC1-2 tumor suppressor controls insulin-PI3K signaling via regulation of IRS proteins. The Journal of Cell Biology, 2004. 166(2): p. 213-223.

46. Vanhaesebroeck, B., L. Stephens, and P. Hawkins, PI3K signalling: the path to discovery and understanding. Nat Rev Mol Cell Biol, 2012. 13(3): p. 195-203.

47. Balla, T., Phosphoinositides: tiny lipids with giant impact on cell regulation. Physiol Rev, 2013. 93(3): p. 1019-137.

48. Vanhaesebroeck, B., et al., The emerging mechanisms of isoform-specific PI3K signalling. Nat Rev Mol Cell Biol, 2010. 11(5): p. 329-41.

49. Jean, S. and A.A. Kiger, Classes of phosphoinositide 3-kinases at a glance. J Cell Sci, 2014. 127(Pt 5): p. 923-8.

50. Becattini, B., et al., PI3Kgamma within a nonhematopoietic cell type negatively regulates dietinduced thermogenesis and promotes obesity and insulin resistance. Proc Natl Acad Sci U S A, 2011. 108(42): p. E854-63.

51. Myers, M.G., Jr., et al., IRS-1 activates phosphatidylinositol 3'-kinase by associating with src homology 2 domains of p85. Proc Natl Acad Sci U S A, 1992. 89(21): p. 10350-4.

52. Ciraolo, E., et al., Phosphoinositide 3-kinase p110beta activity: key role in metabolism and mammary gland cancer but not development. Sci Signal, 2008. 1(36): p. ra3.

53. Manna, P. and S.K. Jain, Phosphatidylinositol-3,4,5-triphosphate and cellular signaling: implications for obesity and diabetes. Cell Physiol Biochem, 2015. 35(4): p. 1253-75.

54. Mazza, S. and T. Maffucci, Class II phosphoinositide 3-kinase C2alpha: what we learned so far. Int J Biochem Mol Biol, 2011. 2(2): p. 168-182.

55. Leibiger, B., et al., Insulin-feedback via PI3K-C2 $\alpha$ activated PKB $\alpha / A k t 1$ is required for glucosestimulated insulin secretion. The FASEB Journal, 2010. 24(6): p. 1824-1837.

56. Dominguez, V., et al., Class II Phosphoinositide 3-Kinase Regulates Exocytosis of Insulin Granules in Pancreatic 6 Cells. Journal of Biological Chemistry, 2011. 286(6): p. 4216-4225.

57. Falasca, M., et al., The role of phosphoinositide 3-kinase C2alpha in insulin signaling. J Biol Chem, 2007. 282(38): p. 28226-36.

58. Alliouachene, S., et al., Inactivation of the Class II PI3K-C2beta Potentiates Insulin Signaling and Sensitivity. Cell Rep, 2015. 13(9): p. 1881-94.

59. Shearin, A.L., et al., Lack of AKT in adipocytes causes severe lipodystrophy. Mol Metab, 2016. 5(7): p. 472-479.

60. Cho, H., et al., Insulin resistance and a diabetes mellitus-like syndrome in mice lacking the protein kinase Akt2 (PKB beta). Science, 2001. 292(5522): p. 1728-31.

61. Fischer-Posovszky, P., et al., Differential function of Akt1 and Akt2 in human adipocytes. Mol Cell Endocrinol, 2012. 358(1): p. 135-43.

62. Alessi, D.R., et al., Mechanism of activation of protein kinase $B$ by insulin and IGF-1. EMBO J, 1996. 15(23): p. 6541-51.

63. Scheid, M.P., P.A. Marignani, and J.R. Woodgett, Multiple phosphoinositide 3-kinasedependent steps in activation of protein kinase B. Mol Cell Biol, 2002. 22(17): p. 6247-60.

64. Sarbassov, D.D., et al., Phosphorylation and regulation of Akt/PKB by the rictor-mTOR complex. Science, 2005. 307(5712): p. 1098-101.

65. Yang, G., et al., A Positive Feedback Loop between Akt and mTORC2 via SIN1 Phosphorylation. Cell Rep, 2015. 12(6): p. 937-43.

66. Yang, H., et al., mTOR kinase structure, mechanism and regulation. Nature, 2013. 497: p. 217.

67. Peterson, T.R., et al., DEPTOR is an mTOR inhibitor frequently overexpressed in multiple myeloma cells and required for their survival. Cell, 2009. 137(5): p. 873-86.

68. Frias, M.A., et al., mSin1 Is Necessary for Akt/PKB Phosphorylation, and Its Isoforms Define Three Distinct mTORC2s. Current Biology, 2006. 16(18): p. 1865-1870.

69. Efeyan, A., et al., Regulation of mTORC1 by the Rag GTPases is necessary for neonatal autophagy and survival. Nature, 2013. 493(7434): p. 679-83.

70. Long, X., et al., Rheb binds and regulates the mTOR kinase. Curr Biol, 2005. 15(8): p. 702-13. 
71. Nojima, H., et al., The Mammalian Target of Rapamycin (mTOR) Partner, Raptor, Binds the $m$ TOR Substrates $p 70$ S6 Kinase and 4E-BP1 through Their TOR Signaling (TOS) Motif. Journal of Biological Chemistry, 2003. 278(18): p. 15461-15464.

72. Magnuson, B., B. Ekim, and D.C. Fingar, Regulation and function of ribosomal protein S6 kinase (S6K) within mTOR signalling networks. Biochem J, 2012. 441(1): p. 1-21.

73. Gingras, A.C., et al., Regulation of 4E-BP1 phosphorylation: a novel two-step mechanism. Genes Dev, 1999. 13(11): p. 1422-37.

74. Zhang, H.H., et al., Insulin Stimulates Adipogenesis through the Akt-TSC2-mTORC1 Pathway. PLOS ONE, 2009. 4(7): p. e6189.

75. Laplante, M. and D.M. Sabatini, Regulation of mTORC1 and its impact on gene expression at a glance. Journal of Cell Science, 2013. 126(8): p. 1713.

76. Carnevalli, L.S., et al., S6K1 plays a critical role in early adipocyte differentiation. Dev Cell, 2010. 18(5): p. 763-74.

77. Zhang, C., et al., Glycerolipid signals alter mTOR complex 2 (mTORC2) to diminish insulin signaling. Proc Natl Acad Sci U S A, 2012. 109(5): p. 1667-72.

78. Zinzalla, V., et al., Activation of mTORC2 by Association with the Ribosome. Cell. 144(5): p. 757768.

79. Oh, W.J., et al., mTORC2 can associate with ribosomes to promote cotranslational phosphorylation and stability of nascent Akt polypeptide. The EMBO Journal, 2010. 29(23): p. 3939.

80. Liu, P., et al., Cell-cycle-regulated activation of Akt kinase by phosphorylation at its carboxyl terminus. Nature, 2014. 508: p. 541.

81. Dibble, C.C., J.M. Asara, and B.D. Manning, Characterization of Rictor Phosphorylation Sites Reveals Direct Regulation of mTOR Complex 2 by S6K1. Molecular and Cellular Biology, 2009. 29(21): p. 5657-5670.

82. Julien, L.-A., et al., mTORC1-Activated S6K1 Phosphorylates Rictor on Threonine 1135 and Regulates mTORC2 Signaling. Molecular and Cellular Biology, 2010. 30(4): p. 908-921.

83. Treins, C., et al., Rictor is a novel target of p70 S6 kinase-1. Oncogene, 2009. 29: p. 1003.

84. Lee, P.L., et al., Raptor/mTORC1 loss in adipocytes causes progressive lipodystrophy and fatty liver disease. Mol Metab, 2016. 5(6): p. 422-32.

85. Tang, Y., et al., Adipose tissue mTORC2 regulates ChREBP-driven de novo lipogenesis and hepatic glucose metabolism. Nat Commun, 2016. 7: p. 11365.

86. Aylett, C.H., et al., Architecture of human mTOR complex 1. Science, 2016. 351(6268): p. 4852.

87. Thoreen, C.C. and D.M. Sabatini, Rapamycin inhibits mTORC1, but not completely. Autophagy, 2009. 5(5): p. 725-726.

88. Bell, A., L. Grunder, and A. Sorisky, Rapamycin inhibits human adipocyte differentiation in primary culture. Obes Res, 2000. 8(3): p. 249-54.

89. Cho, H.J., et al., Regulation of adipocyte differentiation and insulin action with rapamycin. Biochem Biophys Res Commun, 2004. 321(4): p. 942-8.

90. Tremblay, F., et al., Activation of the mammalian target of rapamycin pathway acutely inhibits insulin signaling to Akt and glucose transport in 3T3-L1 and human adipocytes. Endocrinology, 2005. 146(3): p. 1328-37.

91. Pereira, M.J., et al., mTOR inhibition with rapamycin causes impaired insulin signalling and glucose uptake in human subcutaneous and omental adipocytes. Mol Cell Endocrinol, 2012. 355(1): p. 96-105.

92. Danielsson, A., et al., Attenuation of insulin-stimulated insulin receptor substrate-1 serine 307 phosphorylation in insulin resistance of type 2 diabetes. J Biol Chem, 2005. 280(41): p. 3438992.

93. Stralfors, P., Caveolins and caveolae, roles in insulin signalling and diabetes. Adv Exp Med Biol, 2012. 729: p. 111-26. 
94. Thorn, H., et al., Cell surface orifices of caveolae and localization of caveolin to the necks of caveolae in adipocytes. Mol Biol Cell, 2003. 14(10): p. 3967-76.

95. Parpal, S., et al., Cholesterol depletion disrupts caveolae and insulin receptor signaling for metabolic control via insulin receptor substrate-1, but not for mitogen-activated protein kinase control. J Biol Chem, 2001. 276(13): p. 9670-8.

96. Hansen, C.G., et al., Deletion of cavin genes reveals tissue-specific mechanisms for morphogenesis of endothelial caveolae. Nat Commun, 2013. 4: p. 1831.

97. Lajoie, P. and I.R. Nabi, Lipid rafts, caveolae, and their endocytosis. Int Rev Cell Mol Biol, 2010. 282: p. 135-63.

98. Mendez-Gimenez, L., et al., Role of aquaglyceroporins and caveolins in energy and metabolic homeostasis. Mol Cell Endocrinol, 2014. 397(1-2): p. 78-92.

99. Öst, A., et al., Triacylglycerol Is Synthesized in a Specific Subclass of Caveolae in Primary Adipocytes. Journal of Biological Chemistry, 2005. 280(1): p. 5-8.

100. Fagerholm, S., et al., Rapid insulin-dependent endocytosis of the insulin receptor by caveolae in primary adipocytes. PLoS One, 2009. 4(6): p. e5985.

101. Stenkula, K.G., et al., Human, but not rat, IRS1 targets to the plasma membrane in both human and rat adipocytes. Biochem Biophys Res Commun, 2007. 363(3): p. 840-5.

102. Mundy, D.I., et al., Dual control of caveolar membrane traffic by microtubules and the actin cytoskeleton. J Cell Sci, 2002. 115(Pt 22): p. 4327-39.

103. Richter, T., et al., High-resolution $3 D$ quantitative analysis of caveolar ultrastructure and caveola-cytoskeleton interactions. Traffic, 2008. 9(6): p. 893-909.

104. Smith, J.M., A.C. Hedman, and D.B. Sacks, IQGAPs choreograph cellular signaling from the membrane to the nucleus. Trends Cell Biol, 2015. 25(3): p. 171-84.

105. White, C.D., H.H. Erdemir, and D.B. Sacks, IQGAP1 and its binding proteins control diverse biological functions. Cellular signalling, 2012. 24(4): p. 826-34.

106. Hedman, A.C., J.M. Smith, and D.B. Sacks, The biology of IQGAP proteins: beyond the cytoskeleton. EMBO Rep, 2015. 16(4): p. 427-46.

107. Johnson, M., M. Sharma, and B.R. Henderson, IQGAP1 regulation and roles in cancer. Cellular signalling, 2009. 21(10): p. 1471-8.

108. Tekletsadik, Y.K., R. Sonn, and M.A. Osman, A conserved role of IQGAP1 in regulating TOR complex 1. Journal of cell science, 2012. 125(Pt 8): p. 2041-52.

109. Bardwell, A.J., et al., The WW domain of the scaffolding protein IQGAP1 is neither necessary nor sufficient for binding to the MAPKS ERK1 and ERK2. Journal of Biological Chemistry, 2017. 292(21): p. 8750-8761.

110. Vetterkind, S., et al., Hierarchical scaffolding of an ERK1/2 activation pathway. Cell communication and signaling : CCS, 2013. 11: p. 65.

111. Zhou, H., et al., The Ras GTPase-activating-like protein IQGAP1 is downregulated in human diabetic nephropathy and associated with ERK1/2 pathway activation. Molecular and cellular biochemistry, 2014. 391(1-2): p. 21-5.

112. Gustafsdottir, S.M., et al., Proximity ligation assays for sensitive and specific protein analyses. Analytical Biochemistry, 2005. 345(1): p. 2-9.

113. Rittmeyer, E.N., et al., A dual role for IQGAP1 in regulating exocytosis. Journal of Cell Science, 2008. 121(3): p. 391-403.

114. Kimura, T., et al., Activated Cdc42-bound IQGAP1 determines the cellular endocytic site. Mol Cell Biol, 2013. 33(24): p. 4834-43.

115. Wickström, S.A., et al., Integrin-Linked Kinase Controls Microtubule Dynamics Required for Plasma Membrane Targeting of Caveolae. Developmental Cell. 19(4): p. 574-588.

116. Choi, S., et al., Agonist-stimulated phosphatidylinositol-3,4,5-trisphosphate generation by scaffolded phosphoinositide kinases. Nat Cell Biol, 2016. 18(12): p. 1324-1335.

117. Chawla, B., et al., Absence of IQGAP1 Protein Leads to Insulin Resistance. J Biol Chem, 2017. 292(8): p. 3273-3289. 
118. Bartness, T.J., et al., Neural innervation of white adipose tissue and the control of lipolysis. Frontiers in neuroendocrinology, 2014. 35(4): p. 473-93.

119. Tavernier, G., et al., Expression of beta3-adrenoceptors with low lipolytic action in human subcutaneous white adipocytes. Journal of lipid research, 1996. 37(1): p. 87-97.

120. Mauriege, P., et al., Human fat cell beta-adrenergic receptors: beta-agonist-dependent lipolytic responses and characterization of beta-adrenergic binding sites on human fat cell membranes with highly selective beta 1-antagonists. Journal of lipid research, 1988. 29(5): p. 587-601.

121. De Matteis, R., et al., Immunohistochemical identification of the beta(3)-adrenoceptor in intact human adipocytes and ventricular myocardium: effect of obesity and treatment with ephedrine and caffeine. International journal of obesity and related metabolic disorders : journal of the International Association for the Study of Obesity, 2002. 26(11): p. 1442-50.

122. Greenberg, A.S., et al., Isolation of CDNAs for perilipins $A$ and B: sequence and expression of lipid droplet-associated proteins of adipocytes. Proceedings of the National Academy of Sciences of the United States of America, 1993. 90(24): p. 12035-9.

123. Anthonsen, M.W., et al., Identification of novel phosphorylation sites in hormone-sensitive lipase that are phosphorylated in response to isoproterenol and govern activation properties in vitro. The Journal of biological chemistry, 1998. 273(1): p. 215-21.

124. Stralfors, P., P. Bjorgell, and P. Belfrage, Hormonal regulation of hormone-sensitive lipase in intact adipocytes: identification of phosphorylated sites and effects on the phosphorylation by lipolytic hormones and insulin. Proceedings of the National Academy of Sciences of the United States of America, 1984. 81(11): p. 3317-21.

125. Yamaguchi, T., et al., CGI-58 interacts with perilipin and is localized to lipid droplets. Possible involvement of CGI-58 mislocalization in Chanarin-Dorfman syndrome. The Journal of biological chemistry, 2004. 279(29): p. 30490-7.

126. Miyoshi, H., et al., Control of adipose triglyceride lipase action by serine 517 of perilipin A globally regulates protein kinase A-stimulated lipolysis in adipocytes. The Journal of biological chemistry, 2007. 282(2): p. 996-1002.

127. Lass, A., et al., Adipose triglyceride lipase-mediated lipolysis of cellular fat stores is activated by CGI-58 and defective in Chanarin-Dorfman Syndrome. Cell metabolism, 2006. 3(5): p. 309319.

128. Zimmermann, R., et al., Fat mobilization in adipose tissue is promoted by adipose triglyceride lipase. Science, 2004. 306(5700): p. 1383-6.

129. Jenkins, C.M., et al., Identification, cloning, expression, and purification of three novel human calcium-independent phospholipase A2 family members possessing triacylglycerol lipase and acylglycerol transacylase activities. J Biol Chem, 2004. 279(47): p. 48968-75.

130. Villena, J.A., et al., Desnutrin, an adipocyte gene encoding a novel patatin domain-containing protein, is induced by fasting and glucocorticoids: ectopic expression of desnutrin increases triglyceride hydrolysis. J Biol Chem, 2004. 279(45): p. 47066-75.

131. Schweiger, M., et al., Neutral lipid storage disease: genetic disorders caused by mutations in adipose triglyceride lipase/<em>PNPLA2</em> or <em>CGI-58</em>/<em>ABHD5</em>. American Journal of Physiology - Endocrinology and Metabolism, 2009. 297(2): p. E289-E296.

132. Fischer, J., et al., The gene encoding adipose triglyceride lipase (PNPLA2) is mutated in neutral lipid storage disease with myopathy. Nature genetics, 2007. 39(1): p. 28-30.

133. Coassin, S., et al., Investigation and functional characterization of rare genetic variants in the adipose triglyceride lipase in a large healthy working population. PLoS genetics, 2010. 6(12): p. e1001239.

134. Missaglia, S., et al., Late onset of neutral lipid storage disease due to novel PNPLA2 mutations causing total loss of lipase activity in a patient with myopathy and slight cardiac involvement. Neuromuscular disorders : NMD, 2017.

135. Kaneko, K., et al., A novel mutation in PNPLA2 causes neutral lipid storage disease with myopathy and triglyceride deposit cardiomyovasculopathy: a case report and literature review. Neuromuscular disorders : NMD, 2014. 24(7): p. 634-41. 
136. Haemmerle, G., et al., Defective lipolysis and altered energy metabolism in mice lacking adipose triglyceride lipase. Science, 2006. 312(5774): p. 734-7.

137. Kershaw, E.E., et al., Adipose triglyceride lipase: function, regulation by insulin, and comparison with adiponutrin. Diabetes, 2006. 55(1): p. 148-57.

138. Ryden, M., et al., Comparative studies of the role of hormone-sensitive lipase and adipose triglyceride lipase in human fat cell lipolysis. American journal of physiology. Endocrinology and metabolism, 2007. 292(6): p. E1847-55.

139. Bezaire, V., et al., Contribution of adipose triglyceride lipase and hormone-sensitive lipase to lipolysis in hMADS adipocytes. The Journal of biological chemistry, 2009. 284(27): p. 18282-91.

140. Yao-Borengasser, A., et al., Adipose triglyceride lipase expression in human adipose tissue and muscle. Role in insulin resistance and response to training and pioglitazone. Metabolism, 2011. 60(7): p. 1012-20.

141. Steinberg, G.R., B.E. Kemp, and M.J. Watt, Adipocyte triglyceride lipase expression in human obesity. Am J Physiol Endocrinol Metab, 2007. 293(4): p. E958-64.

142. Rydén, M., et al., Comparative studies of the role of hormone-sensitive lipase and adipose triglyceride lipase in human fat cell lipolysis. American Journal of Physiology-Endocrinology and Metabolism, 2007. 292(6): p. E1847-E1855.

143. Haemmerle, G., et al., Hormone-sensitive lipase deficiency in mice causes diglyceride accumulation in adipose tissue, muscle, and testis. The Journal of biological chemistry, 2002. 277(7): p. 4806-15.

144. Albert, J.S., et al., Null mutation in hormone-sensitive lipase gene and risk of type 2 diabetes. The New England journal of medicine, 2014. 370(24): p. 2307-15.

145. Large, V., et al., Decreased expression and function of adipocyte hormone-sensitive lipase in subcutaneous fat cells of obese subjects. Journal of Lipid Research, 1999. 40(11): p. 2059-2065.

146. Ray, H., et al., Depot-specific differences in perilipin and hormone-sensitive lipase expression in lean and obese. Lipids in health and disease, 2009. 8: p. 58.

147. Pereira, M.J., et al., Impaired adipose tissue lipid storage, but not altered lipolysis, contributes to elevated levels of NEFA in type 2 diabetes. Degree of hyperglycemia and adiposity are important factors. Metabolism: clinical and experimental, 2016. 65(12): p. 1768-1780.

148. Stralfors, P. and P. Belfrage, Phosphorylation of hormone-sensitive lipase by cyclic AMPdependent protein kinase. The Journal of biological chemistry, 1983. 258(24): p. 15146-52.

149. Greenberg, A.S., et al., Stimulation of lipolysis and hormone-sensitive lipase via the extracellular signal-regulated kinase pathway. The Journal of biological chemistry, 2001. 276(48): p. 45456-61.

150. Krintel, C., et al., Ser649 and Ser650 are the major determinants of protein kinase A-mediated activation of human hormone-sensitive lipase against lipid substrates. PloS one, 2008. 3(11): p. e3756.

151. Smith, C.J., et al., Hormone-sensitive cyclic GMP-inhibited cyclic AMP phosphodiesterase in rat adipocytes. Regulation of insulin- and cAMP-dependent activation by phosphorylation. J Biol Chem, 1991. 266(20): p. 13385-90.

152. Palmer, D., et al., Protein kinase A phosphorylation of human phosphodiesterase $3 B$ promotes 14-3-3 protein binding and inhibits phosphatase-catalyzed inactivation. J Biol Chem, 2007. 282(13): p. 9411-9.

153. Degerman, E., et al., Evidence that insulin and isoprenaline activate the cGMP-inhibited lowKm cAMP phosphodiesterase in rat fat cells by phosphorylation. Proc Natl Acad Sci U S A, 1990. 87(2): p. 533-7.

154. Wijkander, J., et al., Insulin-induced phosphorylation and activation of phosphodiesterase $3 B$ in rat adipocytes: possible role for protein kinase $B$ but not mitogen-activated protein kinase or p70 56 kinase. Endocrinology, 1998. 139(1): p. 219-27.

155. Kitamura, T., et al., Insulin-induced phosphorylation and activation of cyclic nucleotide phosphodiesterase 3B by the serine-threonine kinase Akt. Mol Cell Biol, 1999. 19(9): p. 628696. 
156. Albert, V., et al., mTORC2 sustains thermogenesis via Akt-induced glucose uptake and glycolysis in brown adipose tissue. EMBO molecular medicine, 2016. 8(3): p. 232-46.

157. Zmuda-Trzebiatowska, E., V. Manganiello, and E. Degerman, Novel mechanisms of the regulation of protein kinase $B$ in adipocytes; implications for protein kinase $A$, Epac, phosphodiesterases 3 and 4. Cell Signal, 2007. 19(1): p. 81-6.

158. Mei, F.C., et al., Differential signaling of cyclic AMP: opposing effects of exchange protein directly activated by cyclic AMP and cAMP-dependent protein kinase on protein kinase $B$ activation. J Biol Chem, 2002. 277(13): p. 11497-504.

159. Brennesvik, E.O., et al., Adrenaline potentiates insulin-stimulated PKB activation via CAMP and Epac: implications for cross talk between insulin and adrenaline. Cellular Signalling, 2005. 17(12): p. 1551-1559.

160. Petersen, R.K., et al., Cyclic AMP (CAMP)-mediated stimulation of adipocyte differentiation requires the synergistic action of Epac- and CAMP-dependent protein kinase-dependent processes. Mol Cell Biol, 2008. 28(11): p. 3804-16.

161. Lafontan, M. and M. Berlan, Fat cell adrenergic receptors and the control of white and brown fat cell function. Journal of lipid research, 1993. 34(7): p. 1057-91.

162. Lafontan, M., et al., Adrenergic regulation of adipocyte metabolism. Hum Reprod, 1997. 12 Suppl 1: p. 6-20.

163. Mauriege, P., et al., Heterogeneous Distribution of Beta-Adrenoceptor and Alpha-2Adrenoceptor Binding-Sites in Human Fat-Cells from Various Fat Deposits - Functional Consequences. European Journal of Clinical Investigation, 1987. 17(2): p. 156-165.

164. Mauriege, P., et al., Regional variation in adipose tissue lipolysis in lean and obese men. J Lipid Res, 1991. 32(10): p. 1625-33.

165. Lonnqvist, F., et al., Lipolytic Catecholamine Resistance Due to Decreased Beta-2-Adrenoceptor Expression in Fat-Cells. Journal of Clinical Investigation, 1992. 90(6): p. 2175-2186.

166. Langin, D., et al., Drop in the "atypical" beta-adrenergic response and modification of the beta/alpha 2-adrenoceptor balance in fat cells from aging rabbits. Endocrinology, 1992. 130(1): p. 307-15.

167. Lefkowitz, R.J., G protein-coupled receptors. III. New roles for receptor kinases and betaarrestins in receptor signaling and desensitization. J Biol Chem, 1998. 273(30): p. 18677-80.

168. Rapacciuolo, A., et al., Protein kinase $A$ and $G$ protein-coupled receptor kinase phosphorylation mediates beta-1 adrenergic receptor endocytosis through different pathways. J Biol Chem, 2003. 278(37): p. 35403-11.

169. Berggreen, C., et al., Protein kinase $B$ activity is required for the effects of insulin on lipid metabolism in adipocytes. Am J Physiol Endocrinol Metab, 2009. 296(4): p. E635-46.

170. Choi, Y.H., et al., Alterations in regulation of energy homeostasis in cyclic nucleotide phosphodiesterase 3B-null mice. J Clin Invest, 2006. 116(12): p. 3240-51.

171. Choi, S.M., et al., Insulin regulates adipocyte lipolysis via an Akt-independent signaling pathway. Molecular and cellular biology, 2010. 30(21): p. 5009-20.

172. DiPilato, L.M., et al., The Role of PDE3B Phosphorylation in the Inhibition of Lipolysis by Insulin. Mol Cell Biol, 2015. 35(16): p. 2752-60.

173. Ahmad, F., et al., Differential regulation of adipocyte PDE3B in distinct membrane compartments by insulin and the beta3-adrenergic receptor agonist CL316243: effects of caveolin-1 knockdown on formation/maintenance of macromolecular signalling complexes. Biochem J, 2009. 424(3): p. 399-410.

174. Rondinone, C.M., et al., Phosphorylation of PDE3B by phosphatidylinositol 3-kinase associated with the insulin receptor. J Biol Chem, 2000. 275(14): p. 10093-8.

175. Resjo, S., et al., Phosphorylation and activation of phosphodiesterase type $3 B$ (PDE3B) in adipocytes in response to serine/threonine phosphatase inhibitors: deactivation of PDE3B in vitro by protein phosphatase type 2A. Biochem J, 1999. 341 ( Pt 3): p. 839-45.

176. Mohan, M.L., et al., Noncanonical regulation of insulin-mediated ERK activation by phosphoinositide 3-kinase gamma. Mol Biol Cell, 2017. 28(22): p. 3112-3122. 
177. Arner, P., et al., The antilipolytic effect of insulin in human adipose tissue in obesity, diabetes mellitus, hyperinsulinemia, and starvation. Metabolism: clinical and experimental, 1981. 30(8): p. 753-60.

178. Desai, K.S., K.C. Li, and A. Angel, Bimodal effect of insulin on hormone-stimulated lipolysis: relation to intracellular 3',5'-cyclic adenylic acid and free fatty acid levels. Journal of lipid research, 1973. 14(6): p. 647-55.

179. RENNER, R., W. KEMMLER, and K.D. HEPP, Antagonism of Insulin and Lipolytic Hormones in the Control of Adenylate-Cyclase Activity in Fat Cells. European Journal of Biochemistry, 1974. 49(1): p. 129-141.

180. Mooney, R.A., R.D. Ebersohl, and J.M. McDonald, Insulin-mediated antilipolysis in permeabilized rat adipocytes. Journal of Biological Chemistry, 1984. 259(12): p. 7701-4.

181. Lafontan, M. and D. Langin, Lipolysis and lipid mobilization in human adipose tissue. Progress in lipid research, 2009. 48(5): p. 275-97.

182. Fruhbeck, G., et al., Regulation of adipocyte lipolysis. Nutr Res Rev, 2014. 27(1): p. 63-93.

183. Blaak, E.E., et al., Microdialysis assessment of local adipose tissue lipolysis during betaadrenergic stimulation in upper-body-obese subjects with type II diabetes. Clin Sci (Lond), 1999. 97(4): p. 421-8.

184. Arner, P., et al., Influence of obesity on the antilipolytic effect of insulin in isolated human fat cells obtained before and after glucose ingestion. J Clin Invest, 1984. 73(3): p. 673-80.

185. Johnson, J.A., et al., Impaired insulin action in subcutaneous adipocytes from women with visceral obesity. Am J Physiol Endocrinol Metab, 2001. 280(1): p. E40-9.

186. Jocken, J.W. and E.E. Blaak, Catecholamine-induced lipolysis in adipose tissue and skeletal muscle in obesity. Physiol Behav, 2008. 94(2): p. 219-30.

187. Wang, T., et al., Metabolic partitioning of endogenous fatty acid in adipocytes. Obes Res, 2003. 11(7): p. 880-7.

188. Hammond, V.A. and D.G. Johnston, Substrate cycling between triglyceride and fatty acid in human adipocytes. Metabolism: clinical and experimental, 1987. 36(4): p. 308-13.

189. Leroyer, S.N., et al., Rosiglitazone controls fatty acid cycling in human adipose tissue by means of glyceroneogenesis and glycerol phosphorylation. J Biol Chem, 2006. 281(19): p. 13141-9.

190. Guan, H.P., et al., A futile metabolic cycle activated in adipocytes by antidiabetic agents. Nat Med, 2002. 8(10): p. 1122-8.

191. Bederman, I.R., et al., Triglyceride synthesis in epididymal adipose tissue: contribution of glucose and non-glucose carbon sources. J Biol Chem, 2009. 284(10): p. 6101-8.

192. Nye, C., et al., Reassessing triglyceride synthesis in adipose tissue. Trends Endocrinol Metab, 2008. 19(10): p. 356-61.

193. Chitraju, C., et al., Triglyceride Synthesis by DGAT1 Protects Adipocytes from Lipid-Induced ER Stress during Lipolysis. Cell Metab, 2017. 26(2): p. 407-418 e3. 



\section{Papers}

The papers associated with this thesis have been removed for copyright reasons. For more details about these see:

http://urn.kb.se/resolve?urn=urn:nbn:se:liu:diva-147618 